Trinity University

Digital Commons@ Trinity

Geosciences Faculty Research

Geosciences Department

2-2009

\title{
Evolution and Stratigraphic Architecture of Marine Slope Gully Complexes: Monterey Formation (Miocene), Gaviota Beach, California
}

Kathleen D. Surpless

TrinityUniversity, ksurples@trinity.edu

R. B. Ward

S. A. Graham

Follow this and additional works at: https://digitalcommons.trinity.edu/geo_faculty

Part of the Earth Sciences Commons

\section{Repository Citation}

Surpless, K.D., Ward, R.B., \& Graham, S.A. (2009). Evolution and stratigraphic architecture of marine slope gully complexes: Monterey formation (miocene), Gaviota beach, California. Marine and Petroleum Geology, 26(2), 269-288. doi:10.1016/

j.marpetgeo.2007.10.005

This Article is brought to you for free and open access by the Geosciences Department at Digital Commons @ Trinity. It has been accepted for inclusion in Geosciences Faculty Research by an authorized administrator of Digital Commons @ Trinity. For more information, please contact jcostanz@trinity.edu. 


\title{
Evolution and stratigraphic architecture of marine slope gully complexes: Monterey Formation (Miocene), Gaviota Beach, California
}

\author{
Kathleen D. Surpless ${ }^{\mathrm{a}, *}$, Richard B. Ward ${ }^{\mathrm{b}}$, Stephan A. Graham ${ }^{\mathrm{c}}$ \\ ${ }^{\mathrm{a}}$ Trinity University, One Trinity Place, San Antonio, TX 78212, USA \\ ${ }^{\mathrm{b}}$ Shell Research and Technology Centre Amsterdam, Badhuisweg 3, 1031 CM, Amsterdam, The Netherlands \\ ${ }^{\mathrm{c}}$ Department of Geological and Environmental Sciences, Stanford University, Stanford, CA 94305 2115, USA
}

Received 27 March 2007; received in revised form 24 September 2007; accepted 1 October 2007

\begin{abstract}
Three small headlands in the sea cliffs west of Gaviota Beach, California, are the remnant fill of three discrete submarine gullies incised into the late Miocene submarine slope environment. These promontories provide excellent, three-dimensional exposure of the gully fill in outcrop, permitting documentation of their complex internal stratigraphic architecture. Detailed study of these exposures elucidates the sedimentologic processes that occur in the filling of slope gullies, guides interpretation of the acoustic records of otherwise unsampled modern gully systems on continental slopes, and provides insight into the heterogeneity that may characterize slope gully petroleum reservoirs.

We develop a comprehensive facies scheme to describe the variability within these intercalated coarse- and fine-grained deposits and use two-dimensional photopans to interpret the overall depositional system. Defined by internal bedforms, sedimentation units, and sediment size, each facies records sedimentation under different hydrodynamic conditions and can be genetically related to a discrete depositional mechanism. We differentiate channel axis, margin, and overbank sub-environments within the gully fill, which together define overall crudely braided, low-sinuosity channels within the gullies. Like many modern gully systems, the Gaviota gullies probably initiated through local slope oversteepening that led to slope failure, slumping, and initiation of sediment flows. Erosion and sedimentation from these high-density turbidity currents formed the primary depositional process for the Gaviota conglomerate units. Once initiated, the gullies acted as sediment conduits from the shelf and possibly onshore regions.

Despite their prevalence on modern upper slopes and their pivotal role in shaping shelf margins and transporting sediment to deeper water, the details of submarine slope gully formation and filling remain obscure. The Gaviota gully complexes provide valuable insights into long-term gully fill attributes not easily obtained from modern slope gully systems and rarely preserved in the rock record.
\end{abstract}

(C) 2007 Elsevier Ltd. All rights reserved.

Keywords: Slope deposit; Submarine gully; Gaviota; Facies architecture; Monterey formation

\section{Introduction}

Significant advances in imaging of the seafloor in deepmarine slope settings during the past decade reveal an unexpected complexity of surface features. Prominent among these features are slope gullies, which were little appreciated until high resolution, planimetric sea-floor imaging became widely available (e.g., Gardner, J.V., et al.,

\footnotetext{
${ }^{*}$ Corresponding author. Tel.: + 12109997365 ; fax: + 12109997090.

E-mail addresses: ksurples@trinity.edu (K.D. Surpless), graham@pangea.stanford.edu (S.A. Graham).
}

2003). Multibeam surveys of localities around the world demonstrate that gullies are common features of the upper portions of marine slopes, including both delta slopes (Chiocci and Normark, 1992) and slopes not associated with fluvial input (Gardner, J.V. et al., 2003). Although there seems to be no consensus definition of the term 'submarine gully', most investigators apply the label to features too small to be called channels or canyons (Fig. 1; Field et al., 1999). Because these features, tens to hundreds of meters wide and at most tens of meters deep, are too small to have been detected or mapped until recently, it is not surprising that the sediment associated 

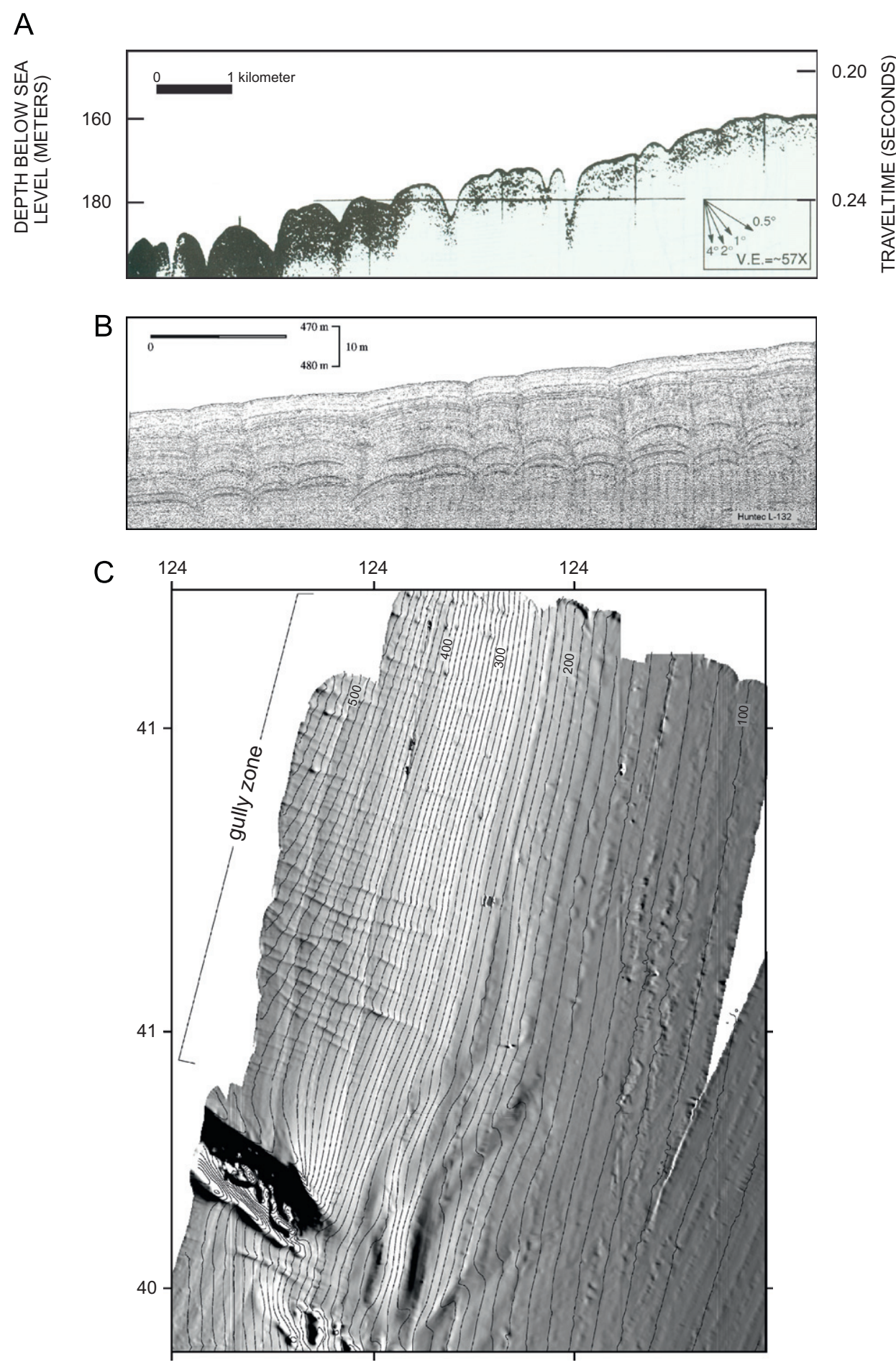

Fig. 1. (A) Echo-sounding profile almost parallel to continental slope showing modern incised gullies on the shelf break and upper slope in front of the Tiber Delta, Tyrrhenian Sea, Italy (modified from Chiocci and Normark, 1992). (B) High-resolution seismic-reflection profile of gullies on the upper slope north of Cape Mendocino, California (Field et al., 1999). (C) Shaded-relief bathymetric image of the outer shelf and slope of the northern California margin, showing the distribution of slope gullies (Field et al., 1999).

with modern slope gullies have seldom been sampled (Chiocci and Normark, 1992) and therefore remain poorly known.

The characteristics of slope gully sedimentation are largely inferred from outcrops of ancient deposits interpreted as gully fills. This approach presents considerable challenges because mud-dominated slope deposits seldom form extensive high-quality outcrops, and it may be difficult to distinguish slope deposits from basin plain deposits in areas of poor exposure and incomplete basin preservation. Even if a slope setting can be confidently inferred, typical cross-sectional outcrops of sand bodies 
A

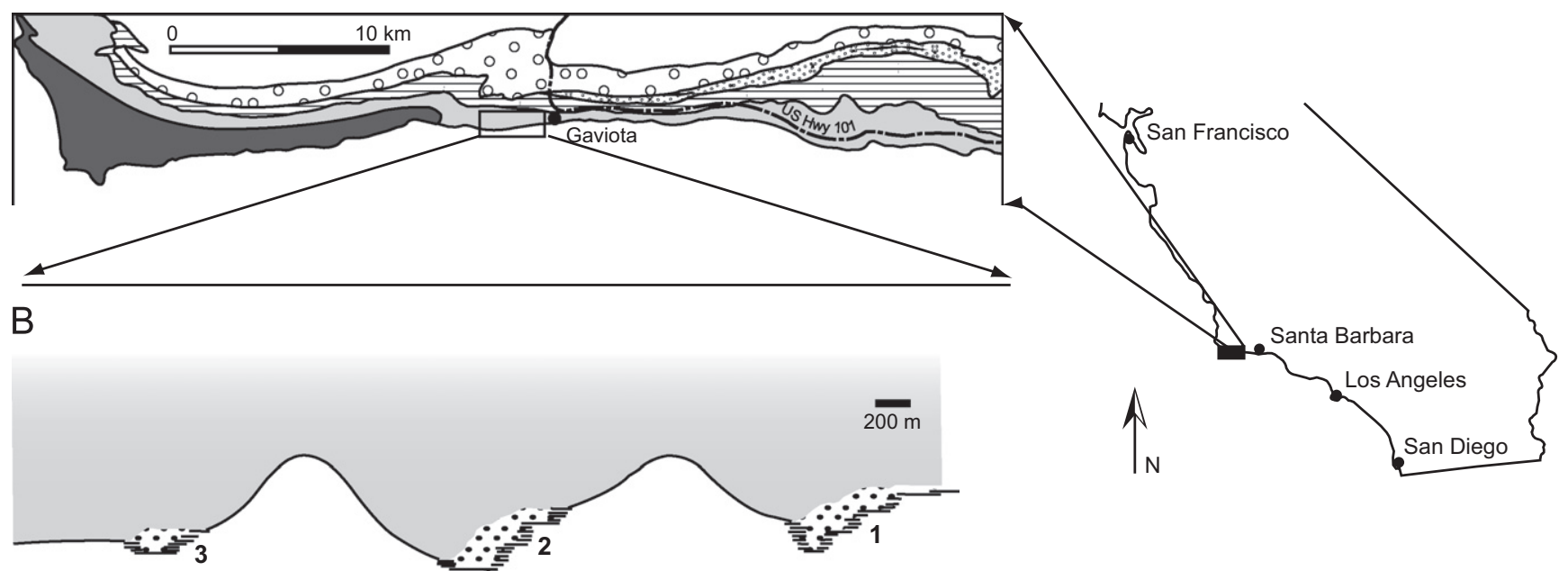

C
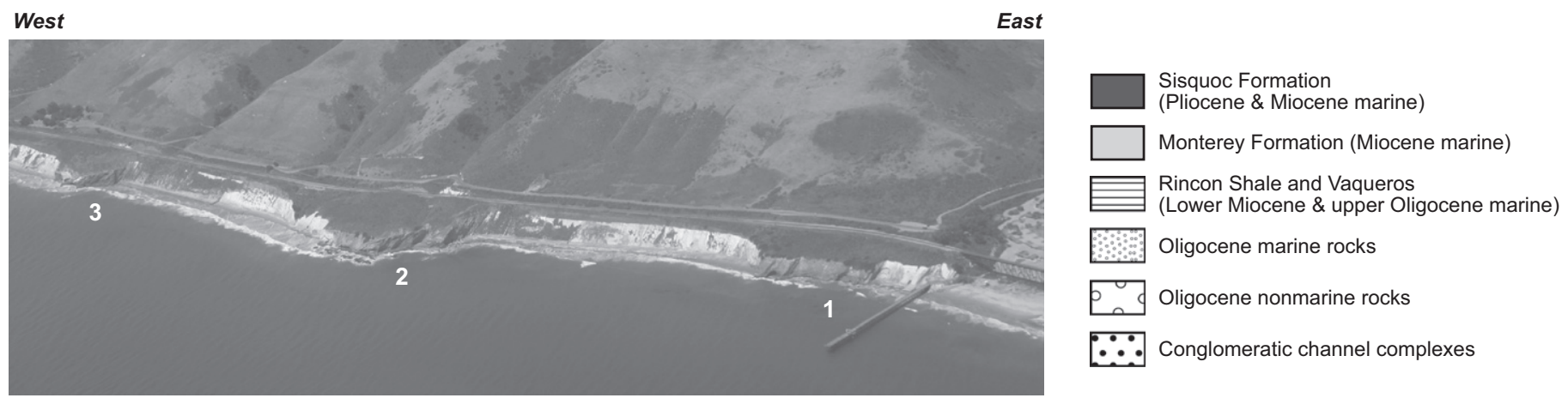

Fig. 2. (A) Geologic map showing the study area within the upper siliceous member of the Monterey Formation exposed in the sea cliff west of Gaviota Beach near Gaviota, California (map modified from Dibblee, 1981). (B) Planimetric map of the Monterey Formation and three incised conglomeratic channel complexes (numbered) measured along the sea cliff west of Gaviota pier and in Gaviota Creek. (C) Oblique aerial view to the northwest shows the three slope gully complexes (numbered) cropping out as dark promontories that jut into the Santa Barbara channel. The dark color of the gully-fill deposits results from saturation by petroleum, now degraded to tar. These slope deposits trend east-west (parallel to the shoreline) and dip $45^{\circ}$ to the south (Dibblee, 1950; Isaacs, 1980).

may be too limited in size to uniquely confirm a channelform morphology indicative of a gully origin.

Three Miocene deep-marine, slope gully deposits wellexposed in sea cliffs west of Gaviota Beach, California (Figs. 2 and 3), contribute significantly to knowledge of the sediment fill of slope gullies. Basin setting and paleobathymetry of the Gaviota slope gullies establish that these gully fills formed at upper bathyal water depths (150-500 m) or slightly deeper on the upper portion of a marine slope (Fig. 4; Isaacs, 2001), and their scale ( $\sim 500 \mathrm{~m}$ wide, $25 \mathrm{~m}$ thick) qualifies them as slope gully deposits rather than canyons, following the usage of Pickering et al. (1989). Biogenic and hemipelagic strata characterize the section of the upper siliceous member of the Miocene Monterey Formation that encases the gully deposits along the east-west coastline between Ventura and Point Conception (Fig. 2). The Gaviota Beach exposures provide a rare opportunity to study the complex sedimentary fabrics and stratigraphic relations within the gully complexes. Fully tar-impregnated, these outcrops also provide an excellent analog for slope gully petroleum reservoirs, such as have been inferred elsewhere in the subsurface (Hewlett and Jordan, 1993).

This study documents the detailed facies architecture of the three slope gully deposits exposed at Gaviota Beach to improve understanding of the sedimentologic processes that occur in the filling of slope gullies. Our results provide both a basis for interpreting the acoustic records of otherwise unsampled modern gully systems on continental slopes, and insight into the heterogeneity that may characterize slope gully petroleum reservoirs.

\section{Marine slope gullies}

Despite their potential as both significant down-slope sediment conduits (Dott and Bird, 1979; Field and Clarke, 1979) and petroleum reservoirs (Hewlett and Jordan, 1993), submarine gullies have received relatively limited attention. Shepard (1965) defines slope and sea gullies as straight, shallow incisions in the foreset slope of advancing 

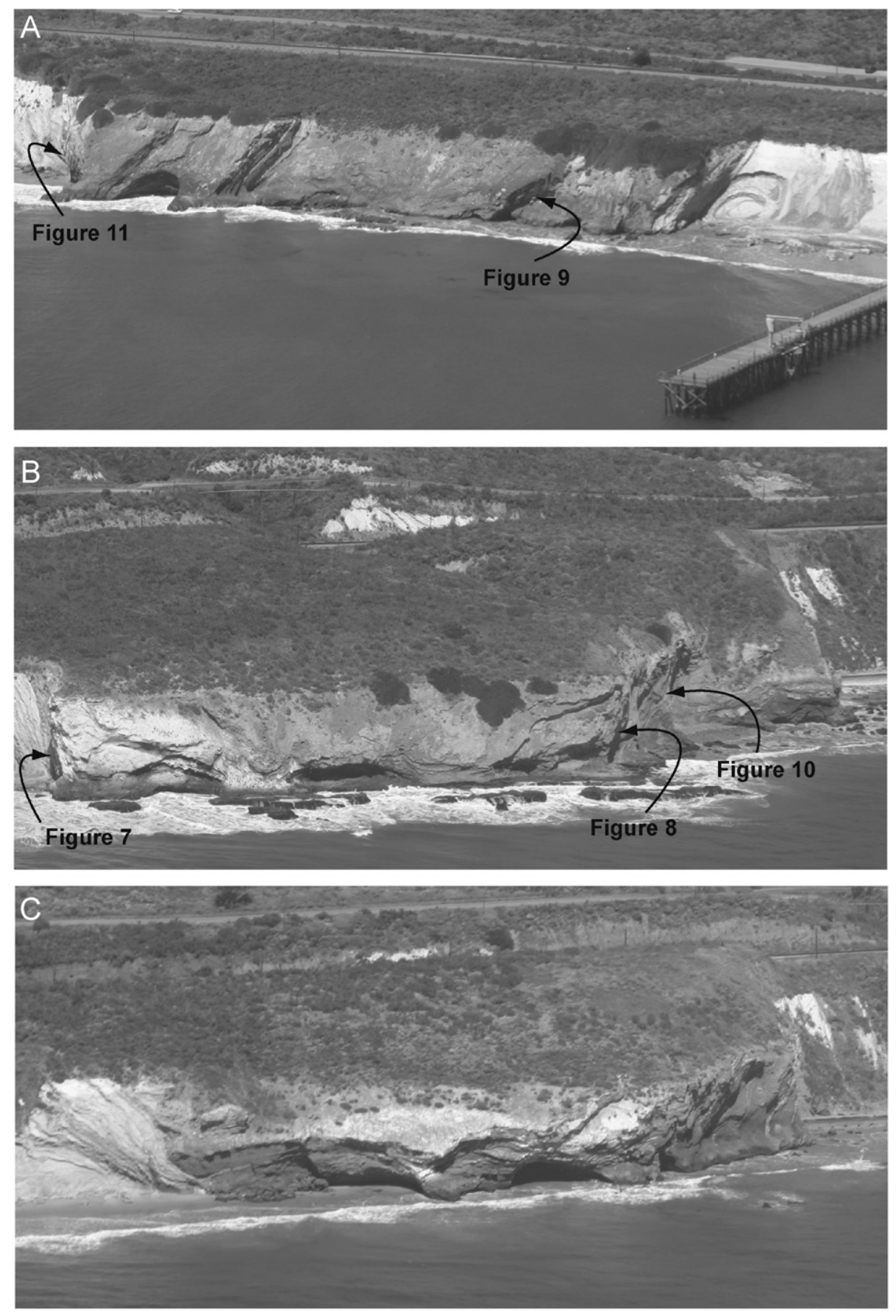

Fig. 3. Oblique aerial views of the three conglomeratic channel complexes with two-lane road near top of each image and the Gaviota fishing pier in (A) for scale. Locations for sections shown in Figs. 8-11 are indicated in (A) and (B). The third channel complex, depicted in (C), was not studied in detail.

deltas that do not extend beyond the upper slope, as observed on the pro-delta slope of the Tiber River, offshore Italy (Chiocci and Normark, 1992). Buffington and Moore (1963) use a broader definition of sea gullies to include all downslope-trending submarine channels that range in size from barely discernable to sea valleys and are common in a variety of submarine environments. Pickering et al. (1989) also take a broader view, defining submarine gullies as linear submarine sediment conduits that are an order of magnitude smaller than canyons, and commonly occur associated with canyons but also occur independently along continental slopes.

A bathymetric survey of a gullied area off of Del Mar, California, reveals numerous gullies whose characteristics may prove typical of slope gullies more generally; the Del Mar gullies are 203-274 m wide with 18-30 m of relief, and extend about a kilometer in length (Inderbitzen and Simpson, 1971). Similar to gullies documented off of San Clemente, California, by Buffington and Moore (1963), the Del Mar gullies incise the upper edge of the basin slope, 

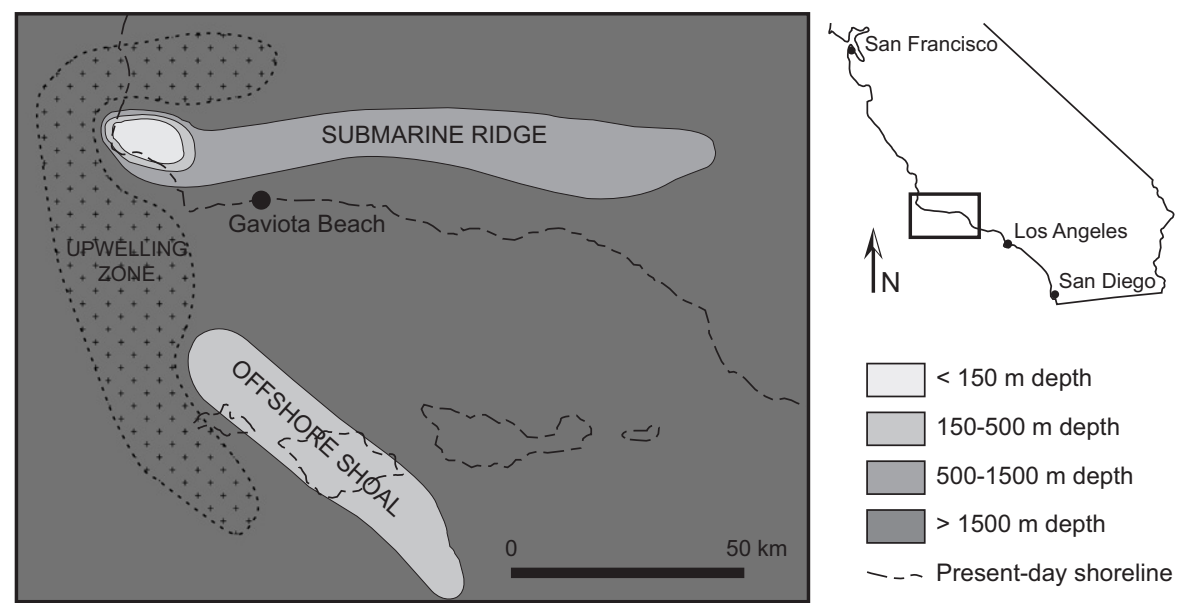

Fig. 4. Paleogeographic map of the Gaviota Beach region during Miocene time showing upper slope setting of the Gaviota gully deposits (modified from Isaacs, 2001).

Table 1

\begin{tabular}{llllll}
\hline Location & Width $(\mathrm{m})$ & Relief $(\mathrm{m})$ & Length $(\mathrm{km})$ & Spacing $^{\mathrm{a}}(\mathrm{m})$ & Water depth $(\mathrm{m})$ \\
\hline Del Mar slope, California $^{\mathrm{b}}$ & $203-274$ & $18-30$ & 1 & & $140-290$ \\
Tiber Delta, Italy $^{\mathrm{c}}$ & $200-500$ & $\leqslant 10$ & $2-6.5$ & $750-1500$ & $150-360$ \\
Santa Monica Bay, California $^{\mathrm{d}}$ & $100-200$ & $<4$ & $\leqslant 6$ & $100-500$ & $160-560$ \\
Eel River Basin, California $^{\mathrm{c}}$ & $75-550$ & $1-2$ & - & $180-1000$ & $380-550$ \\
Gaviota Beach, California $^{\mathrm{f}}$ & $300-600$ & $20-30 ; 5^{\mathrm{g}}$ & - & $1000-1500$ & Upper bathyal (150-500) \\
\hline
\end{tabular}

${ }^{\mathrm{a}}$ Thalweg to thalweg distance.

${ }^{\mathrm{b}}$ Inderbitzen and Simpson (1971).

${ }^{\mathrm{c} C h i o c c i}$ and Normark (1992).

${ }^{\mathrm{d}}$ Gardner, J.V. et al. (2003).

${ }^{\mathrm{e}}$ Field et al. (1999).

${ }^{\mathrm{f}}$ This study.

${ }^{\mathrm{g}}$ Compacted relief of complex, lesser number estimates instantaneous relief.

have concave longitudinal profiles with the coarsest sediment fraction near the gully head, and probably formed through erosion by turbidity currents following submarine slumping or subaerial exposure and erosion (Inderbitzen and Simpson, 1971).

Commonly found associated with larger canyon systems or feeding downslope to larger slope channels (Fig. 1; Field et al., 1999), slope gullies serve as loci for trapping and transporting sediment moving across the shelf and may be volumetrically significant in moving sediment downslope into basins (Dott et al., 1979; Field and Clarke, 1979). Large-scale submarine mass transport is well established in the southern California borderland, but the absence of well-documented small-scale slope features likely reflects the limited resolving power of acoustic imaging, as well as the broader scope of most studies (Field and Clarke, 1979).

Recent application of three-dimensional seismic-reflection imaging, improved seismic resolution, and development of high-resolution multibeam mapping systems provides a much clearer understanding of the bathymetric distribution and dimensions of modern and Pleistocene marine slope gullies (Table 1; e.g., Chiocci and Normark,
1992; Field et al., 1999; Gardner, J.V., 2003; HughesClarke and Mayer, 1996; Posamentier and Basden, 2000; Spinelli and Field, 2001), revealing their importance in upper slope settings between 150 and $600 \mathrm{~m}$ water depth. The improved acoustic resolution enables identification of gullies as modest as 1-2 m deep (Table 1; Field et al., 1999) and shows that many form composite stratigraphic complexes reflecting alternate periods of erosion and aggradation (Chiocci and Normark, 1992; Field et al., 1999). Inferring lithofacies is a principal challenge in interpreting two-dimensional, three-dimensional, and multibeam surveys of modern seafloor and shallowly buried slope gully systems. The few efforts designed to directly sample modern gully systems, such as the recovery of 21 cores in slope gullies off of San Clemente, California, by Inderbitzen and Simpson (1971), tend to sample blanketing muddy Holocene sediments, and therefore may miss coarser-grained detritus associated with active sediment transport earlier in gully history.

The limited literature on ancient outcropping slope channel and gully systems tends to emphasize lower-slope channels and their relationship to lobe and fan systems 
(e.g., Gardner, M.H., et al., 2003). Upper-slope gullies in the rock record are less documented, because of the difficulty of identifying slope deposits, poor outcrop quality, and the small scale and low relief of gullies (e.g., Spinelli and Field, 2001). Surlyk (1987) documents slope gully deposition in the Upper Jurassic Hareelv Formation now exposed in outcrop in East Greenland. The Greenland gully-fill sand deposits range from half a meter to $50 \mathrm{~m}$ thick with irregular bed shapes and erosive bases, are hundreds of meters wide, and up to $5 \mathrm{~km}$ long (Surlyk, 1987). The gullies represent high volume, strongly erosive, high-density turbidity-current deposits that interrupted continuous background hemipelagic deposition in poorly oxygenated deep water (Surlyk, 1987). Ricketts and Evenchick (1999) describe Jurassic conglomerate-filled gullies along the northern margin of the Bowser Basin, British Columbia, that formed through slumping at the shelf break, creating topography that focused graveldominated sediment transport during relative sea-level lowstands. The Bowser Basin gullies contain dominantly debris-flow conglomerate and served as a primary conduit for sediment transport from shelf to slope and deeper water (Ricketts and Evenchick, 1999).

Hewlett and Jordan (1993) identify the up-slope pinchout of channelized, gully-fill turbidite sandstone sequences in the San Joaquin basin of California as one of the principal stratigraphic trap types in the upper Miocene Stevens turbidite sandstones. The Stevens sandstone slope gullies are approximately $61 \mathrm{~m}$ deep and $2.4 \mathrm{~km}$ wide and appear to connect with basinal channel fill downdip (Hewlett and Jordan, 1993). Cores from the gully-fill sediment contain amalgamated, poorly to moderately sorted, coarse-grained sandstone and conglomerate which Hewlett and Jordan (1993) interpret as channel lags deposited by large-volume sediment gravity flows, as well as deposits from smaller flows during gully backfilling.

In sum, despite their pivotal role in shaping shelf margins and transporting sediment to deeper water, as well as their prevalence on modern upper slopes (e.g., Field et al., 1999; Pratson and Coakley, 1996; Ricketts and Evenchick, 1999; Spinelli and Field, 2001), few submarine gully deposits have been documented in the rock record, and the details of their formation and filling remain obscure. The Gaviota gully complexes therefore provide valuable insights into long-term gully fill attributes not easily obtained from modern slope gully systems.

\section{Slope gully deposits at Gaviota Beach}

\subsection{Geologic setting}

The Miocene Monterey Formation of California is one part of a thick succession of strata that record deposition from Late Cretaceous through early Pliocene time in the Santa Barbara coastal region (e.g., Dibblee, 1950). The Monterey Formation represents the basinal phase of a Neogene cycle of basin formation and filling (Ingle, 1973,
1975, 1980), resulting in at least three successive lithofacies: carbonate-bearing siliceous rocks at the base of the formation, calcareous phosphatic organic shale in a middle transitional unit, and carbonate-free siliceous facies at the top of the formation (Pisciotto and Garrison, 1981).

The onset of Neogene strike-slip plate motion led to deep basin formation (Atwater, 1970; Blake et al., 1978; Cole and Armentrout, 1979; Howell et al., 1980) with rapid subsidence and low terrigenous input, resulting in a series of starved basins that filled with pelagic and hemipelagic sediment (Ingle, 1980). During early Miocene time, calcareous plankton dominated this basin fill, but by the middle Miocene, the expansion of the East Antarctic ice sheet led to intense upwelling in eastern boundary current areas (Kennett, 1977), which resulted in high diatom productivity and sedimentation (e.g., Ingle, 1980; Pisciotto and Garrison, 1981; Woodruff and Savin, 1985). The diatomaceous facies of the upper Monterey Formation extends through over $1000 \mathrm{~km}$ of discontinuous outcrop along the California margin, and was deposited from about 12-13 Ma (middle Serravallian; Miocene stages after Berggren et al., 1995) into Pliocene time (about $5 \mathrm{Ma}$ ), when increased terrigenous sediment supply resulting from greater tectonism and uplift of the Coast Ranges ended diatomaceous sedimentation (Pisciotto and Garrison, 1981). The Gaviota conglomeratic gully deposits occur in the uppermost strata of the upper siliceous members of the Monterey Formation.

Burial diagenesis has altered the originally diatomaceous Monterey sediment to opal-CT porcelanite, resulting in a near $50 \%$ reduction in volume and loss of index fossils (Isaacs, 1980). However, early-formed dolomitic concretions insulated diatom frustules from burial diagenesis and thus provide biostratigraphic control in the section of the upper siliceous member exposed at Gaviota Beach. At Gaviota Beach, Hornafius and Lagle (1984) dated the base of the upper siliceous member at $7.9-8.4 \mathrm{Ma}$ and the middle at 5.1-5.3 Ma. Accounting for sediment compaction, these ages suggest a true sediment-accumulation rate of $40-50 \mathrm{~m}$ per million years.

The lithologic character and biofacies of the upper siliceous member of the Monterey Formation at Gaviota Beach suggest deposition at upper bathyal or slightly greater depths in an upper slope setting (Fig. 4; Isaacs, 2001). The dominant rock type is laminated to massive silty diatomite that alternates with massive, burrowed beds, suggesting deposition near the edge of the oxygen minimum zone on the basin slope (Pisciotto and Garrison, 1981). The high number of oxygen-minimum benthic foraminifera present, combined with abundant radiolarians and planktonic foraminifera and very few trace fossils, indicates offshore, deeper-water slope conditions (Govean and Garrison, 1981). The presence of shallow-water taxa within the foraminiferal assemblages provides evidence of downslope displacement in the slope environment, and small-scale slump scars, micro-unconformities, and small-scale slump folds further reflect slope instability (Pisciotto and Garrison, 1981). 
North-south compression in the Pliocene and Pleistocene led to oblique left lateral and reverse faulting which uplifted and deformed the Transverse Ranges, creating a series of Pleistocene marine terraces and shifting depocenters to the west (Cole and Armentrout, 1979; Yeats, 1979). This uplift exposed the upper siliceous portion of the Monterey Formation, including the incised conglomeratic channel complexes at Gaviota. Folds in both the Monterey Formation siliceous shale and in the channel complexes themselves provide evidence for continued deformation of the Neogene basin as a result of tectonism related to motion along faults of the larger San Andreas fault system on this active margin.

\subsection{Overview of gully-fill deposits}

The three conglomeratic gully complexes are spaced approximately one kilometer apart in a $40^{\circ}$ south-dipping, east-west trending strike section (Fig. 2). Because of the excellent exposure of the upper siliceous member of the Monterey Formation at Gaviota, the stratigraphic distribution of the three gullies incised into it can be accurately measured. The bases of Gullies 1 and 2 are nearly concordant, and the base of the westernmost Gully 3 is $20 \mathrm{~m}$ upsection from the eastern gullies (Fig. 2). The tops of each of the complexes are in the modern-day surf zone. The gully complexes are $300-600 \mathrm{~m}$ wide, $20-30 \mathrm{~m}$ thick, and their longitudinal extent remains undocumented. Detailed subsurface data are not available to determine if these three conglomerate-filled gullies merge down paleoslope.

Field relations reveal a gradual westward shift in the main gully axes through time. The stratigraphically lowest deposits within the gully fill are on the eastern flank of the outcrops, whereas subsequent deposits shift to the west (Fig. 2). Inter-gully sheet sandstone units or laminated and massive inter-gully siliceous shale dominate the western flank of each gully outcrop. These sheet sandstone beds extend only meters to tens of meters beyond the gully margins, and surf zone and offshore reef sampling of inter-gully facies revealed no sandstone or secondary channels, suggesting that no depositional communication existed between the three gullies along this line of paleoslope.

Paleocurrent directions were determined from flute casts and pebble-drag lineations in Gully 1 (Fig. 5), rare ripple and dune cross-stratification in Gullies 1 and 2 (Fig. 5), and well-developed cobble imbrication in Gullies 2 and 3. All three complexes show a southerly flow direction with about $60^{\circ}$ east-west dispersion, indicating that the late Miocene slope trended approximately east-west and dipped to the south (Fig. 4). These paleocurrent results confirm that the modern outcrops provide transverse cross-sectional views of the three ancient gullies. Sediment relations indicate that the gullies built cumulatively by cut-and-fill processes, although a master scour surface that encloses the entire gully fill could be missed in the nearly dip-surface
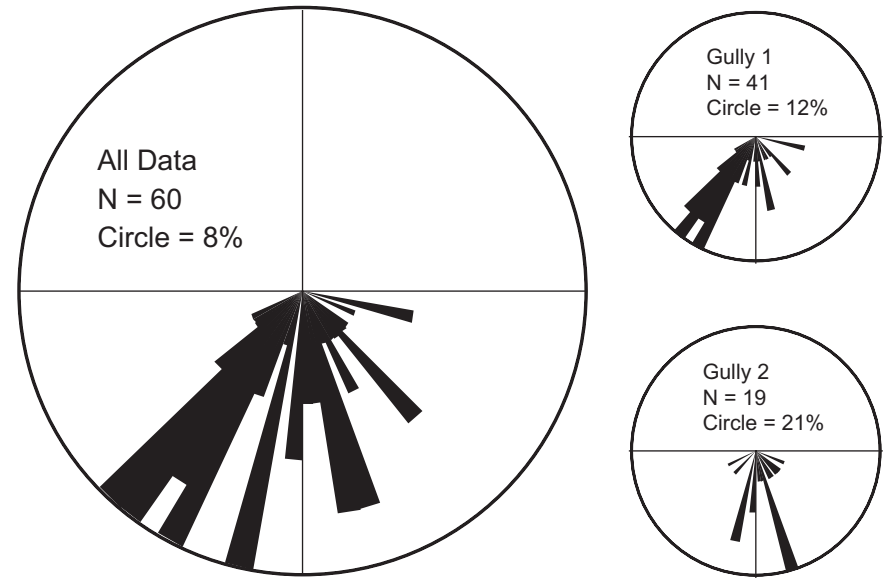

Fig. 5. Paleocurrent directions for Gullies 1 and 2 were measured from pebble drag lineation (unidirectional), flute casts (unidirectional), and channel margin lineation (bi-directional; only southerly directions shown, consistent with unidirectional indicators). Pebble imbrication measurements (not shown) are consistent with plotted dispersal directions.

orientation of the encasing Monterey shale. The individual channels within the gully-fill are up to $5 \mathrm{~m}$ thick.

The coarse-grained gully-fill strata are dark brown or black, in dramatic contrast to the enveloping buff biosiliceous strata (Fig. 2), reflecting the fact that nearly all porous and permeable lithofacies are petroleumsaturated. Thus, although now degraded to tar in the outcrop, the Gaviota slope-gullies are exhumed petroleum pools.

\subsection{Slope gully facies}

Individual sedimentation units within the gully complexes display radical grain size and thickness changes laterally, rendering a vertical bed-by-bed facies designation inadequate. Accordingly, we use two-dimensional photopans to better capture lithofacies and develop a comprehensive facies scheme to account for variability within these intercalated coarse- and fine-grained deposits. The facies are distinguished based on internal bedforms, sedimentation units, and sediment size; thus, each facies records sedimentation under different hydrodynamic conditions and can be genetically related to a discrete depositional mechanism. We use the term 'gully' to refer to the three major coarse-grained complexes exposed on the Gaviota sea cliff (Figs. 2 and 3), and restrict the term 'channel' to individual filled erosional features that sum to form the gully complexes.

\subsubsection{Facies 1: conglomerate}

Conglomeratic facies 1 comprises the majority of the gully fill in a sequence of stacked small channel fills (Fig. 6A). Bed thickness averages $30 \mathrm{~cm}$ and ranges from 20 to $60 \mathrm{~cm}$ thick for individual flows and up to $2 \mathrm{~m}$ thick for amalgamated sedimentation units. Beds extend laterally tens of meters with frequent and abrupt lateral variations in thickness and abundant erosional amalgamation 

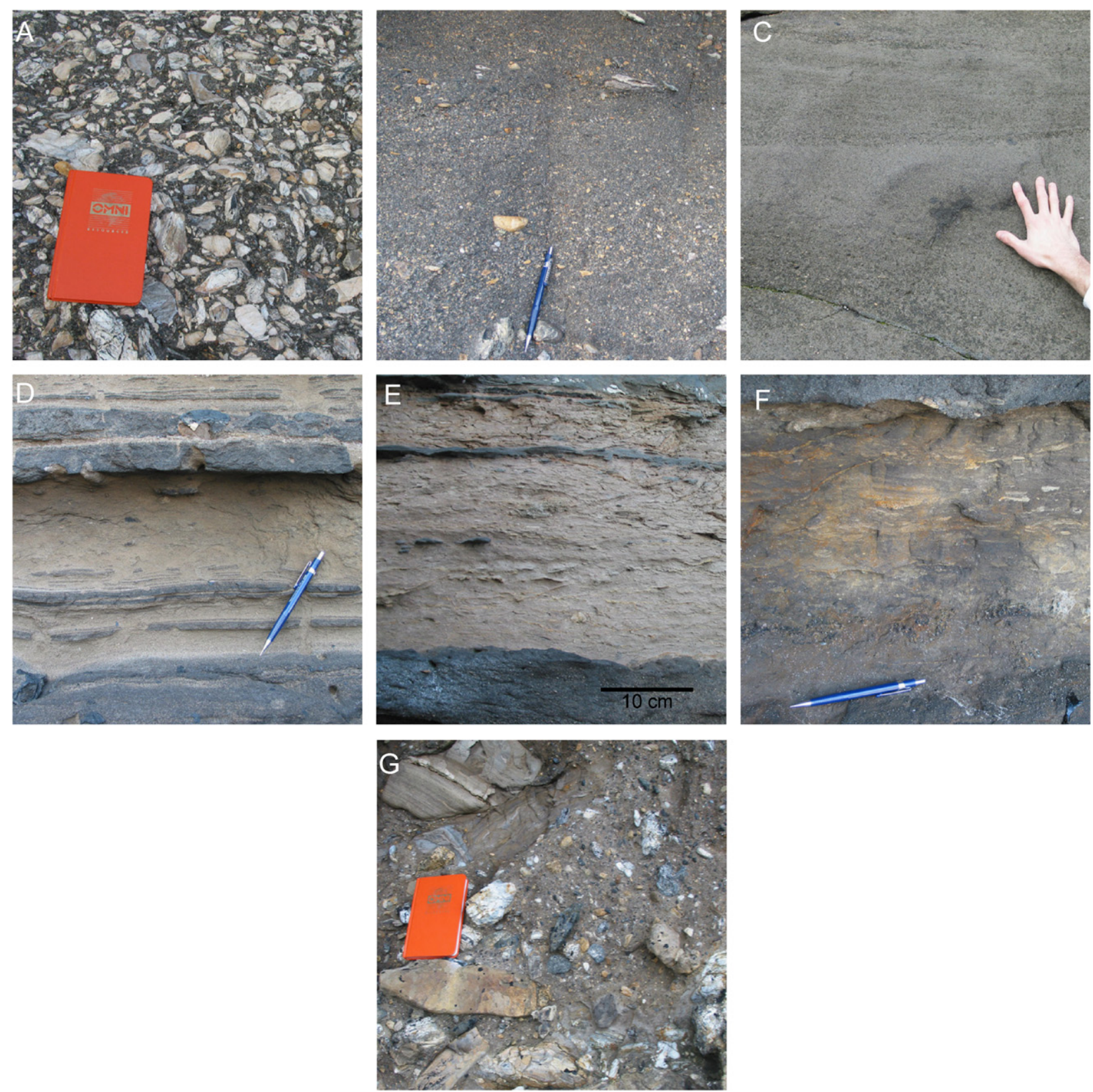

Fig. 6. (A) Pebble and cobble conglomerate facies (notebook is $19 \mathrm{~cm}$ long); (B) pebbly sandstone facies (pencil is $14 \mathrm{~cm}$ long); (C) sandstone facies (two normally graded beds); (D) thin-bedded sandstone facies, interbedded with muddy siltstone (pencil is $14 \mathrm{~cm}$ long); (E) sandy siltstone facies; (F) mudstone facies (mottled from bioturbation); and (G) debris flow facies (notebook is $19 \mathrm{~cm}$ long).

surfaces and bed truncations. Intercalated sandy and silty layers may form discontinuous partings between beds, but are often completely lacking because of amalgamation of the conglomeratic strata.

Bed bases are scoured and flat-parallel to highly irregular. The conglomerate units are clast supported with a nearly mud-free sandy matrix of medium to very coarse sand, and are frequently matrix-supported near the top of beds. The internal structure of these beds generally consists of a $2-10 \mathrm{~cm}$ thick inversely graded horizon at the base, followed by an ungraded or normally graded top, although grading may be completely absent. Imbrication of clasts is present, but not common.
Clasts range from pebble to cobble size, with a few outsize boulder clasts, and are both intra- and extrabasinal. Clasts of the encasing Monterey shale tend to be tabular and angular, ranging from cobble to small boulder in size. Pebble to small cobble-sized clasts of rounded volcanic and quartzite rocks are also common, and indicate an extrabasinal source. Ward (1984) concluded that the source of these rounded, durable, and extrabasinal clasts could only be the recycled fluvial gravels of the underlying Oligocene Sespe Formation (Fig. 2) exposed during uplift to the north (Fig. 4).

Facies 1 represents deposition from high-density turbulent flows. Facies 1 conglomerate typically displays a 
traction-carpet layer overlain by massive, clast-supported chaotic to normally graded sediments deposited from suspension, and are classified as R2 and R3 deposits according to Lowe's (1982) model of deposition for gravelly high-density turbidity currents.

\subsubsection{Facies 2: pebbly sandstone}

The pebbly sandstone facies (Fig. 6B) displays the same bedding styles as Facies 1 and also is confined to channelized deposits. Deposits range in thickness from 10 to $110 \mathrm{~cm}$ and tend to maintain a tabular geometry but can be truncated by successive flow deposits and commonly show great lateral thickness variability.

Facies 2 beds consist of massive to normally graded lower medium to upper coarse sand and pebbles, and may show inverse grading in the basal $3-5 \mathrm{~cm}$ of the pebbly fraction. The pebble component may also be dispersed throughout the sand flow, forming a coarse-tail inversegraded base followed by coarse-tail normal grading. The top of Facies 2 beds often displays planar lamination.

Facies 2 is closely associated with Facies 1 conglomerate and represents channel-axis deposition from waning highdensity turbidity flow (S1 and S2 divisions of Lowe, 1982). Facies 2 may also be transitional between channel-axis and channel-margin facies.

\subsubsection{Facies 3: sandstone}

The sandstone facies is composed of upper fine to lower coarse sand with local gravel concentrations (Fig. 6C). Beds range in thickness from 10 to $60 \mathrm{~cm}$ and show significant lateral variation, often pinching out into muddy siltstone or onlapping oblique scour surfaces of channel margins. Stacked beds are commonly separated by amalgamation surfaces, but may be intercalated with muddy siltstone. The bases of Facies 3 beds can be highly erosive.

Facies 3 consists of upper fine to lower coarse sand that is often laminated and may contain faint traction carpets of medium to coarse sand horizons. Grading is normal overall. Facies 3 sandstone beds represent the final stages of deposition from suspension of a high-density turbidity flow (S2 and S3 divisions of Lowe, 1982) and occur most frequently along the channel margins and less commonly in the channel axes.

\subsubsection{Facies 4: thin-bedded sandstone}

Thin-bedded sandstone facies (Fig. 6D) form beds $1-10 \mathrm{~cm}$ thick, with an average thickness of about $3 \mathrm{~cm}$, and are intercalated with muddy siltstone (Facies 5). The tops and bottoms of the sandstone beds are sharp and well defined by an abrupt contrast in grain size. When deposited between nested channels within the channel complexes, thin sandstone beds are disrupted by bioturbation and bed surfaces display sand injection and flame structures, have loaded bases, and may be planar-laminated near the top of each bed. Facies 4 sandstone beds are normally graded coarse to medium sand, and tend to be coarser-grained within the channel complex. Away from the conglomeratic channels, thin sandstone beds are tabular with minor scour structures at the base and may show high-angle ripple cross-stratification. Still further away, sandstone sheets are discontinuous and lenticular, and may show starved ripple lamination. These beds mark the lateral limit of coarse clastic deposition associated with each gully complex and can be traced into the Monterey Formation siliceous shale for $10-15 \mathrm{~m}$ along strike.

Facies 4 thin-bedded sandstone represents deposition from residual low-density turbidity currents as overbank sheet sandstone beds near the gully margins and interchannel and possible levee deposits within the gully.

\subsubsection{Facies 5: sandy siltstone}

Siltstone occurs within the gullies as $1-150 \mathrm{~cm}$ thick beds, and is commonly intercalated with thin sandstone beds of Facies 4 (Fig. 6E). The base of each siltstone bed is planar, but the overall geometry of the bed depends on the erosive capacity of subsequent flows. Sandy siltstone beds are bioturbated and commonly contain coarse sand-filled tubular burrows $13 \mathrm{~cm}$ in diameter. Facies 5 beds are commonly massive and consist of homogenized very fine sand and silt, but typically show relict planar laminations. Tops of beds are frequently loaded, with flames of siltstone protruding into overlying sandstone. The sandy siltstone deposits may represent overbank sedimentation associated with nearby channels, or waning-flow deposits associated with low-density turbidity currents.

\subsubsection{Facies 6: massive mudstone}

Beds of mudstone $30-70 \mathrm{~cm}$ thick (Fig. 6F) are the only facies within the gullies to maintain thickness and lateral continuity across an entire exposed gully deposit. The beds are extremely tabular, and often appear massive and mottled because of extensive bioturbation. These mudstone beds represent background sedimentation of hemipelagic debris in a deep-marine environment and occur between channels within each gully complex.

\subsubsection{Facies 7: debrite}

Chaotic, extremely poorly sorted, clay matrix-supported deposits of $10-110 \mathrm{~cm}$ thickness occur both near the gully margin and within gullies on steep channel margins (Fig. 6G). Away from the gully margin, chaotic deposits contain clasts of medium-grained sandstone and pebbly sandstone within a silty matrix; but near the gully margins, clasts are dominated by siliceous shale of the Monterey Formation. Clast sizes range from 1 to $40 \mathrm{~cm}$ long, and deposits locally contain outsize blocks up to $3 \mathrm{~m}$ in length. These chaotic deposits represent debris flow deposits generated by slumping of gully margins and intra-gully channel margins.

\subsubsection{Facies 8: siliceous shale}

The siliceous shale facies represents the inter-gully slope environment of pelagic/hemipelagic sedimentation in a 
deep-marine slope environment and comprises the bulk of the upper Monterey Formation.

\subsection{Gully sub-environments and facies associations}

The three-dimensional exposures of the Gaviota sea-cliff outcrops permit identification of channel axis, margin, and overbank sub-environments within the gully complexes through recognition of lateral and vertical associations of facies. Channel axis environments are easily recognized where coarse clastic sediments of Facies 1-3 infill and onlap scoured siliceous shale, mudstone, or sandy siltstone (e.g., Figs. 7-10). Channel margins contain little to no conglomerate, thinner sandstones, and interbedded Facies 4 and 5 sandstone and siltstone (e.g., Fig. 10). Sheet sandstone beds intercalated with siliceous shales and associated with the channel margin represent out-of-gully overbank deposition. The bioturbated mudstone of Facies 6 forms the hemipelagic drape covering the channel fill and represents a hiatus in clastic sediment transport and deposition in the gullies. Facies 8, the Monterey Formation siliceous shale, encases the gullies but is not found within

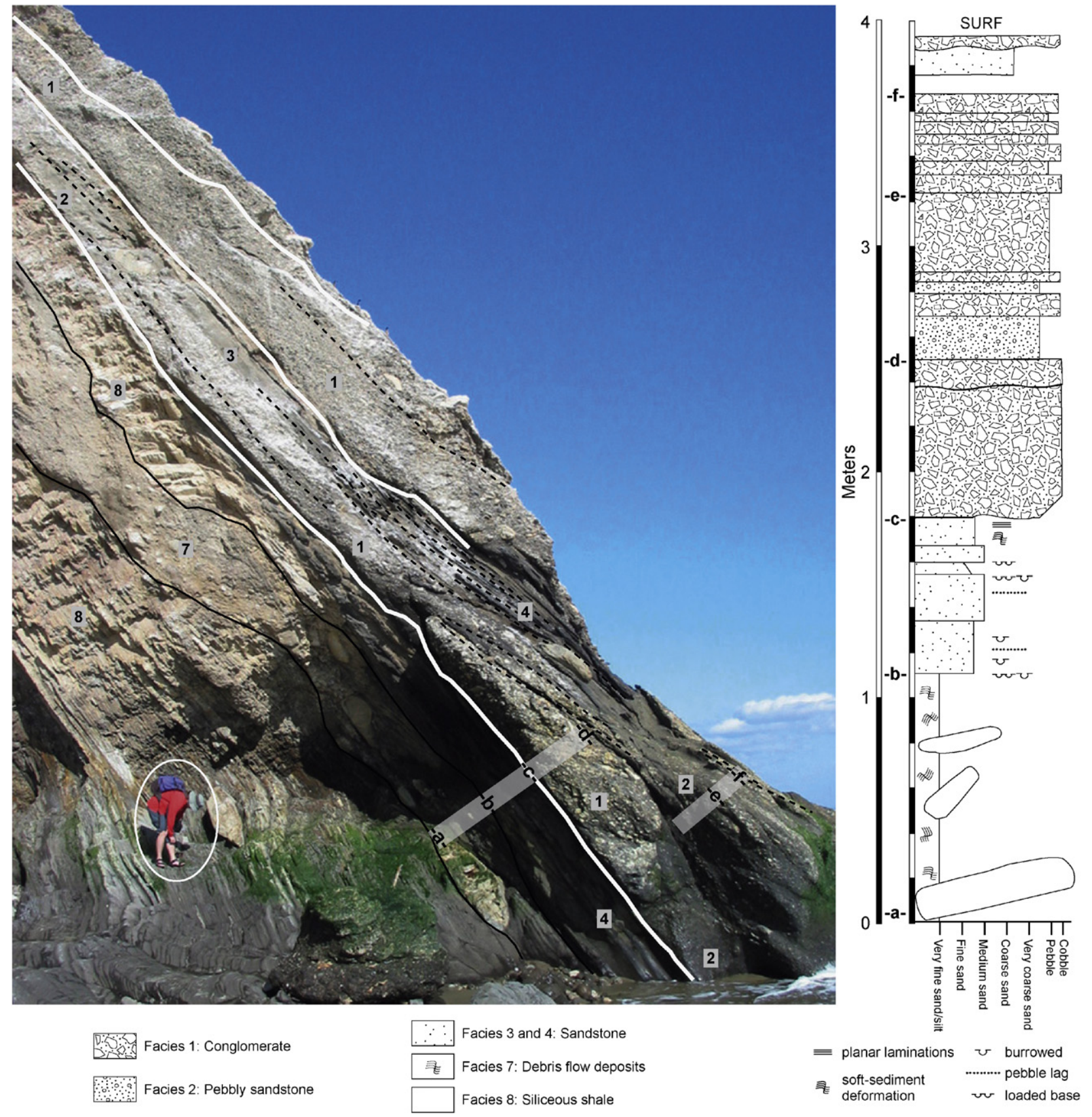

Fig. 7. Channel axis facies exposed in this oblique dip section of the western margin of Gully 2 (location shown on Fig. 3). White lines represent scour surfaces, the solid black line demarcates a large slump deposit, and dotted black lines mark individual beds within the channel axis deposits. Location of measured section at right indicated near base of photo, and facies are labeled in black boldface numbers. Note the numerous scour surfaces and amalgamated channels in this outcrop section. Person in lower left (circled) provides scale. 


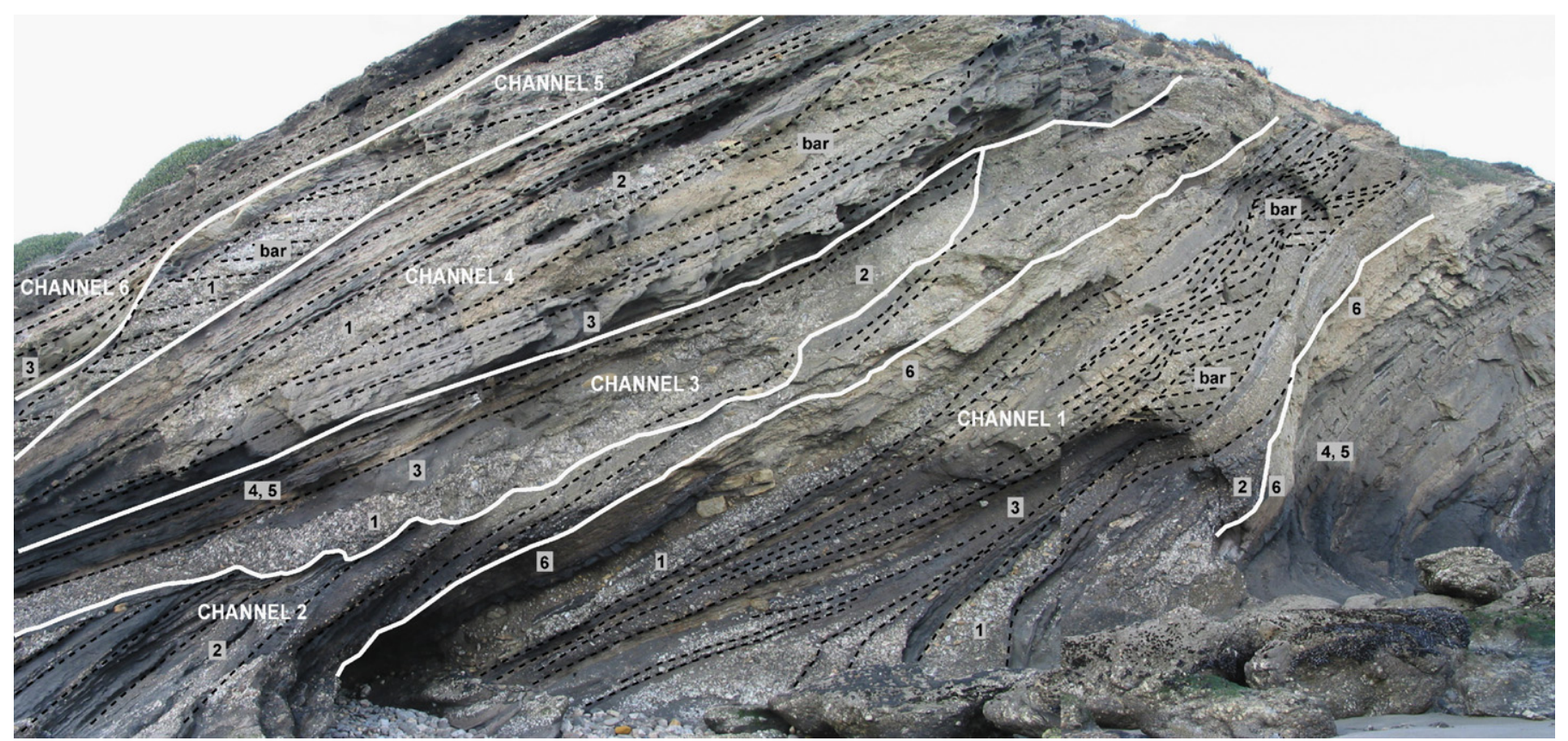

Fig. 8. Channel axis deposits are contained within six nested channel systems in this oblique view of Gully 2 (location shown on Fig. 3). The six nested channel systems are labeled in white; solid white lines demarcate the base of each channel system; dashed black lines indicate individual beds within each channel system; numbers indicate facies.

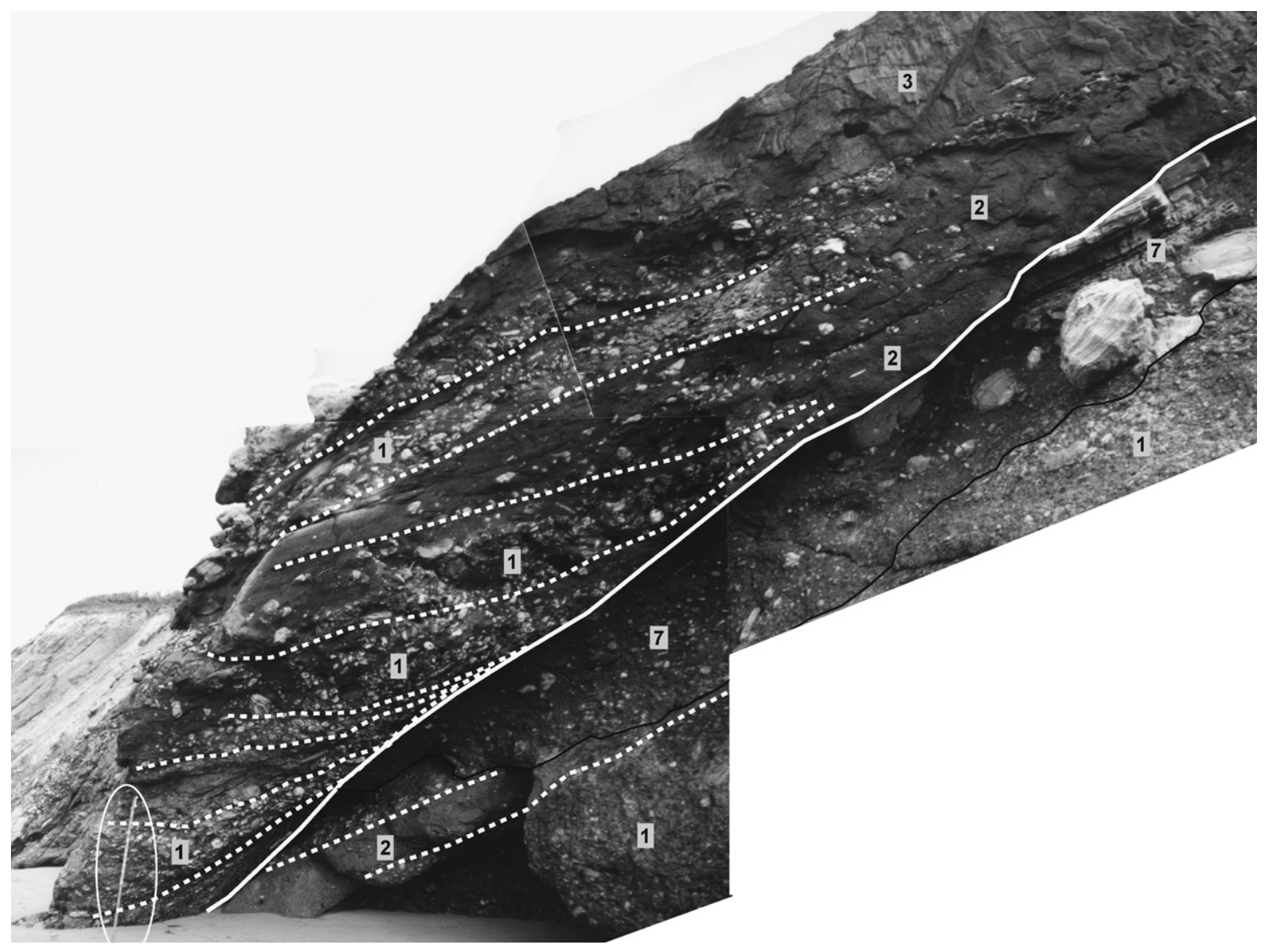

Fig. 9. Amalgamated channel axis deposits exposed in a large channel sequence within Gully 1 (see Fig. 3 for location). Failure of the channel margin led to large debris flow deposit demarcated by thin black line. Scour surface marked by solid white line and individual beds marked by dashed white lines. Note the rapid lateral transitions between Facies 1, 2, and 3 (labeled in boldface numbers) in this outcrop. Circled Jacob staff in lower left provides scale. 


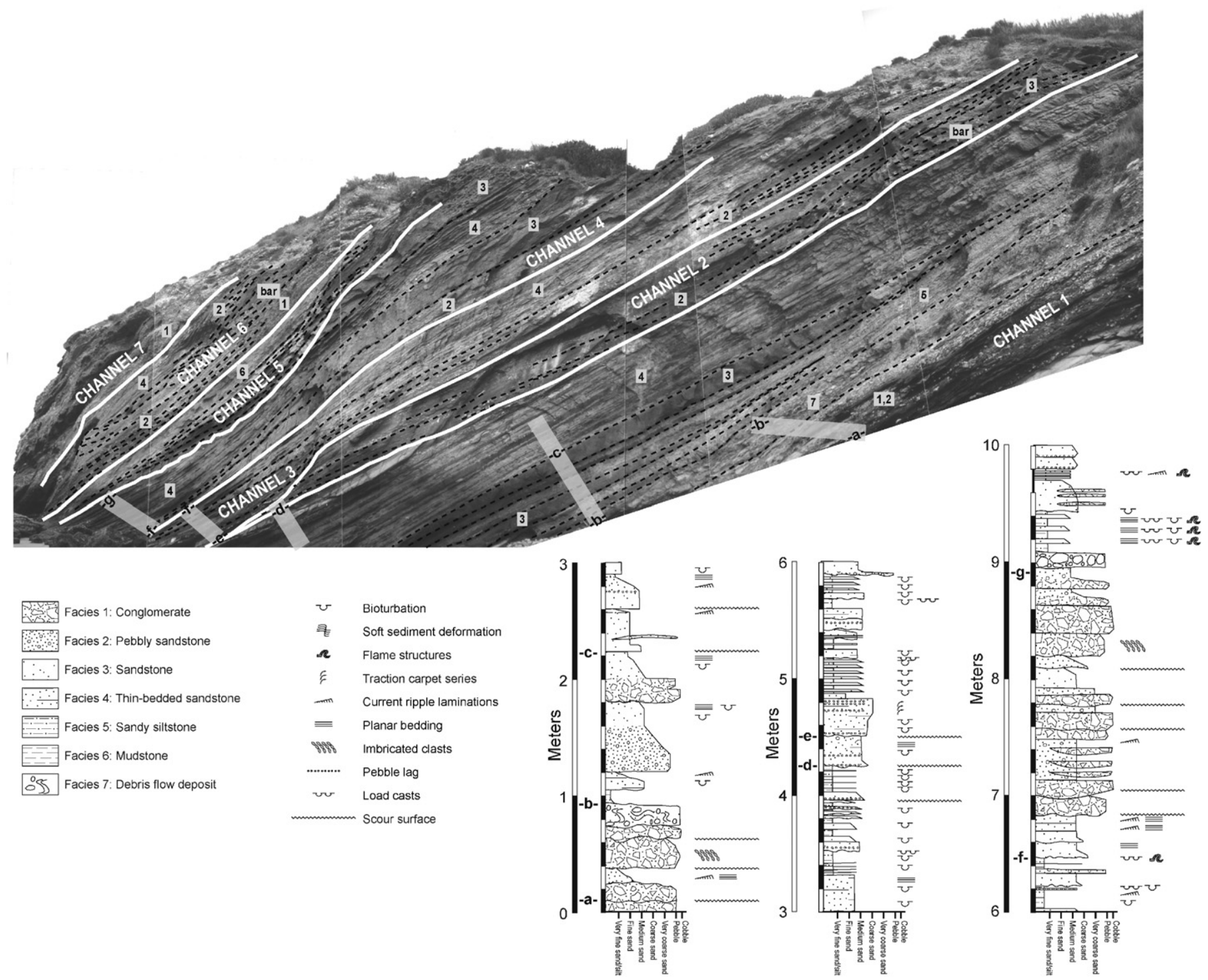

Fig. 10. Channel axis and margin facies displayed in the dip section of Gully 2 (location shown on Fig. 3). The seven nested channel systems are labeled in white; solid white lines demarcate scour surfaces that form the base of each channel system. Black boldface numbers indicate facies and dashed black lines indicate individual beds within each channel system. Location of measured sections indicated by thick dark gray bars near base of photo. See text for discussion of features.

them. Because the small scale of the gully deposits results in rapid lateral facies changes, a single exposed dip-section may contain elements of all three major sub-environments.

\subsubsection{Channel axis deposits}

Channel geometries depend on the erosive capability of flow events and subsequent scouring by later flows, resulting in channel widths of $10-80 \mathrm{~m}$ and depths of $1-5 \mathrm{~m}$. Channel axis deposits at the western margin of Gully 2 illustrate the erosive power of the high-density flows, as well as abrupt vertical and lateral textural variability (Fig. 7; see Fig. 3 for location). A large debris flow deposit represents failure of the western gully margin and contains several outsize clasts of siliceous shale up to $2 \mathrm{~m}$ long (between markers a and b, Fig. 7). The debris flow deposit itself varies from tens of centimeters to over $2 \mathrm{~m}$ thick near the cliff top. Well-bedded fine to medium sandstone beds with loaded bases, numerous burrows, and minor soft-sediment deformation sit on top of the debrisflow deposit at the level of the measured section (between markers b and c, Fig. 7), but pinch out laterally into siliceous shale resting on the debris flow higher up the cliff face. Marker c (Fig. 7) indicates the first significant scour surface at the base of a series of amalgamated conglomerate beds of Facies 1. The sandy-matrix-supported conglomerate grades from pebble to cobble conglomerate with chaotic clast distribution above the base. Clasts are dominantly siliceous shale, average $8 \mathrm{~cm}$ long, and are supported in a matrix of pebbly coarse sand. At least one amalgamation surface is present between markers $\mathrm{c}$ and $\mathrm{d}$ on the measured section. Above this first erosive flow are a series of Facies 2 pebbly sandstone and thinner Facies 1 
cobble conglomerate beds in close association between markers $\mathrm{d}$ and $\mathrm{f}$. The Facies 2 pebbly sandstone is truncated by subsequent conglomerate deposits up the cliff face, and may grade laterally into cobble conglomerate toward the base of the cliff and below beach level. Conglomerate beds above this pebbly sandstone are clastsupported and chaotic, with thin cobble beds in a pebbly sand matrix. Several thick, amalgamated cobble conglomerate deposits are visible higher up the cliff face, but are eroded at beach level.

Fig. 8 shows an oblique outcrop of Gully 2 with six nested channel sequences and the contact relationships between them. Stratigraphically lowest, channel 1 incises a $120 \mathrm{~cm}$ thick bed of Facies 6 mudstone. At beach level, channel 1 contains a series of four conglomerate deposits with inversely graded bases and normally graded tops. Above the conglomerates, a series of Facies 2 and 3 sandstones grades laterally and thickens into cross-stratified Facies 1 and 2 beds. The undulatory upper contact of these beds defines the top of several dune-forms. The presence of reactivation surfaces within the dunes suggests that the dunes were built episodically during times of dynamic flow conditions and migrated in pulses rather than through continued sedimentation. The location of the dune forms in the middle of the channels suggests that they formed as midchannel bars. Overlying the bars are beds of Facies 1-3 that mimic the sinusoidal geometry of the underlying crossstratified beds. The entire channel 1 sequence is capped by a tabular bed of Facies 1 and 2 coarse clastics and nearly a meter of Facies 6 mudstone.

The oversteepened attitude of beds in channel 2 (Fig. 8) may be a result of post-depositional soft-sediment deformation in which the entire channel sequence slid to the south. These deposits were then truncated by the basal conglomerate of channel 3. Facies 3-5 build away from the coarse-grained channel in the center of the photograph before truncation by channel 4 . The overall channel 4 sequence coarsens and thickens laterally toward the top of the sea cliff. Bar forms defined by oblique stratification are preserved in the channel axis exposed near the top of the cliff. Channels 5 and 6 lie at nearly the same stratigraphic level, illustrating the complex scour and fill relationships associated with switching channel courses.

The main channel axis deposits in Gully 1 (Fig. 9; see Fig. 3 for location) contain numerous amalgamation surfaces, as well as the coarsest conglomerate of any of the channel deposits and the thickest accumulation of sediment within an individual channel $(5 \mathrm{~m})$. The conglomeratic beds in this series of flows have inversely graded bases and normally graded tops typical of Facies 1, and the Facies 3 sandstone beds are massive to normally graded. The upper channel axis deposits onlap a large debris flow deposit (Facies 7, best exposed in upper right of photo) containing up to $3 \mathrm{~m}$ blocks of Monterey Formation siliceous shale, which is in turn resting on more Facies 1 and 2 channel axis deposits. The upper package of conglomerate fills scours that were incised into both the debris flow and the conglomerate units below. The entire thick conglomerate and sand package is nearly black due to saturation by hydrocarbons, but the muddy matrix of the debris flow is uncharged.

\subsubsection{Channel margin deposits}

The channel margin sub-environment displays the greatest diversity of facies and bed geometries. Coarser-grained, amalgamated deposits of Facies 2 onlap steep incisional channel flanks, and finer-grained, wedge-shaped beds of Facies 3 and 4 pinch out into the sandy siltstone of Facies 5. Locally sheet sandstone beds of Facies 4 merge into or are truncated by channel margin sandstone beds of Facies 3. Most of the exposed channels display a lateral separation of grain sizes that can occur over short distances. Fig. 9 shows coarse conglomerate of Facies 1 laterally grading into amalgamated sandstone of Facies 3 through a very short transitional zone of Facies 2 pebbly conglomerate. At the outer margins of the gullies, channel margin sandstone units pinch out into laminated siliceous shale of Facies 7 (e.g., Fig. 7). Rare debris-flow deposits of Facies 7 also occur in the channel margin sub-environment.

Fig. 10 shows several nested channels within Gully 2; channel margin facies are finer-grained lateral equivalents of coarser conglomerate exposed in this dip section (see Fig. 3 for location). The white lines mark scour surfaces where conglomerate (Facies 1) and/or laterally equivalent pebbly sandstone (Facies 2) incised the sandy siltstone of Facies 5 and/or the hemipelagic drape of Facies 6. Assuming that these mudstone and siltstone units represent intervals between coarse clastic deposition, these scour horizons delimit channelized turbidite packages.

The beds between markers a and b (Fig. 10) consist of amalgamated conglomerate at the top of channel 1 , overlain by a slump deposit formed as a result of failure of the oversteepened channel margin. The slump deposit is overlain by finer-grained deposits that contain normally graded to massive thin sandstone beds, which pinch out laterally up slope into muddy siltstone and likely represent overbank deposits associated with a channel buried below the modern surf zone. Beds between $b$ and $\mathrm{c}$ form $\mathrm{a}$ sequence of normally graded sandstone beds interbedded with siltstone. The sandstone beds thicken upward near c and contain low-angle accretion surfaces with pebble lag deposits. The grading, upward thickening, accretionary surfaces, and their occurrence interbedded with siltstone suggest that these sandstone beds are equivalent to coarser channel axis deposits now buried below the modern beach level. A $2 \mathrm{~m}$ thick sequence of Facies 4 tabular, thinbedded, normally graded overbank sandstones interbedded with Facies 5 siltstones occurs between $\mathrm{c}$ and $\mathrm{d}$.

A $20 \mathrm{~cm}$ thick bed of channel 2 pebbly sandstone exposed between the scour surfaces at $d$ and $e$ is cut out of the section down dip by channel 3, a minor channel deposit containing thin beds of Facies 2-4. Facies 5 siltstone overlies channel 3 , and is scoured by channel 4 . Channel 4 deposits are transitional between channel axis 


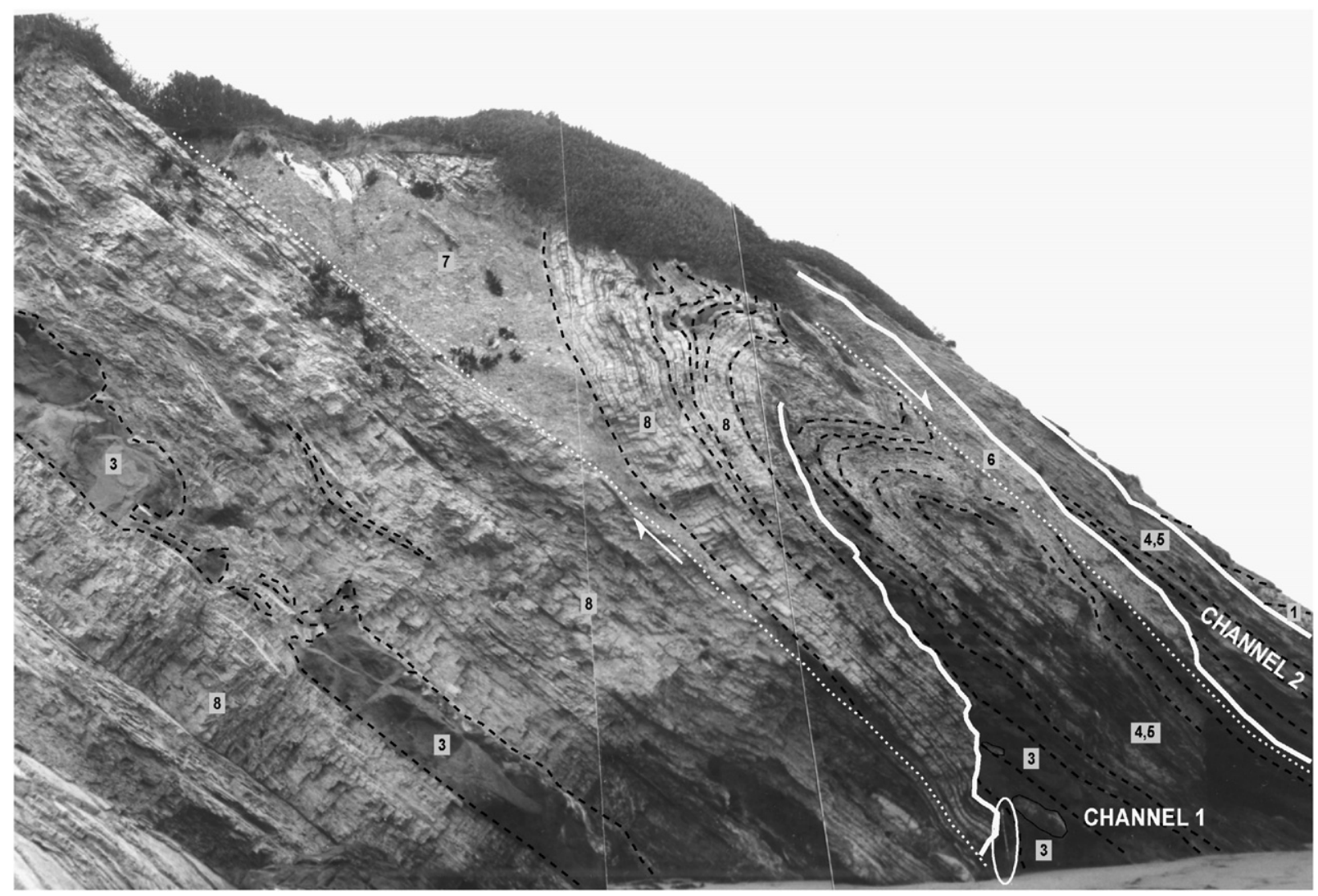

Fig. 11. Oblique view of the western margin of Gully 1 (see Fig. 3 for location). The fold is post-lithification and shear planes are indicated by dotted white lines. Scour surfaces are shown in white, individual beds are traced by dashed black lines, and facies are indicated by boldface numbers. Note the distribution of overbank sandstone beds and channel margin facies within the siliceous shales of the Monterey Formation inside the fold. Circled Jacob staff on the beach provides scale.

below beach level and channel margin and overbank deposits up dip. Individual conglomeratic sedimentation units are commonly less than $20 \mathrm{~cm}$ thick (amalgamated beds are up to $50 \mathrm{~cm}$ thick), and grade abruptly into pebbly sandstone up dip. Above marker $\mathrm{g}$ is another scour with a thin debris flow deposit overlain by thin-bedded Facies 4 sands and Facies 5 siltstone overbank deposits. The presence of Facies 6 mudstone at the tops of channels 5 and 6 suggests periods of reduced clastic sediment transport and deposition during gully filling.

\subsubsection{Overbank deposits}

Along the western flank of Gully 1 (Fig. 11), channelized sandstone and conglomerate beds can be traced directly into thin laterally discontinuous sandstone beds of Facies 4. The fold in Fig. 11 is a post-lithification tectonic feature; shear planes indicated by dotted white lines are evident in outcrop above and below the fold. The channelized sandstone beds overlie truncated siliceous shale of Facies 8 , and overbank strata exposed above and below the channel margin occur as lateral equivalents of the channel margin sands. These sand sheets were deposited in the overbank sub-environment from the tops of turbidity currents that cascaded down the slope and spilled over channel margins. The non-erosive bases and ripple bedforms typical of these medium- to coarse-grained sandstone beds indicate that they were transported by tractive processes as the sands fell out of turbulent suspension. Measured ripple cross-stratification in overbank sands suggests a southerly flow direction consistent with the dispersal direction of the channels within the gullies, indicating that overbank deposition was strongly influenced by paleoslope.

\section{Discussion}

\subsection{Gully-fill characteristics and inferred processes}

The primary depositional process for the Gaviota conglomerate units was sedimentation from high-density turbidity currents. Pebble and cobble imbrication, traction carpets, and laminations indicate that tractive processes dominated; the complete absence of dish structures or other water-escape features, combined with the limited proportion of fine-grained sedimentation suggests that very little material settled out of suspension. Given the overall coarseness of the deposits and the large-scale sedimentary structures, the Gaviota gully fill likely represents deposition in the upper reaches of the system that may have occurred even on a relatively steep slope. Proximal deposition of 

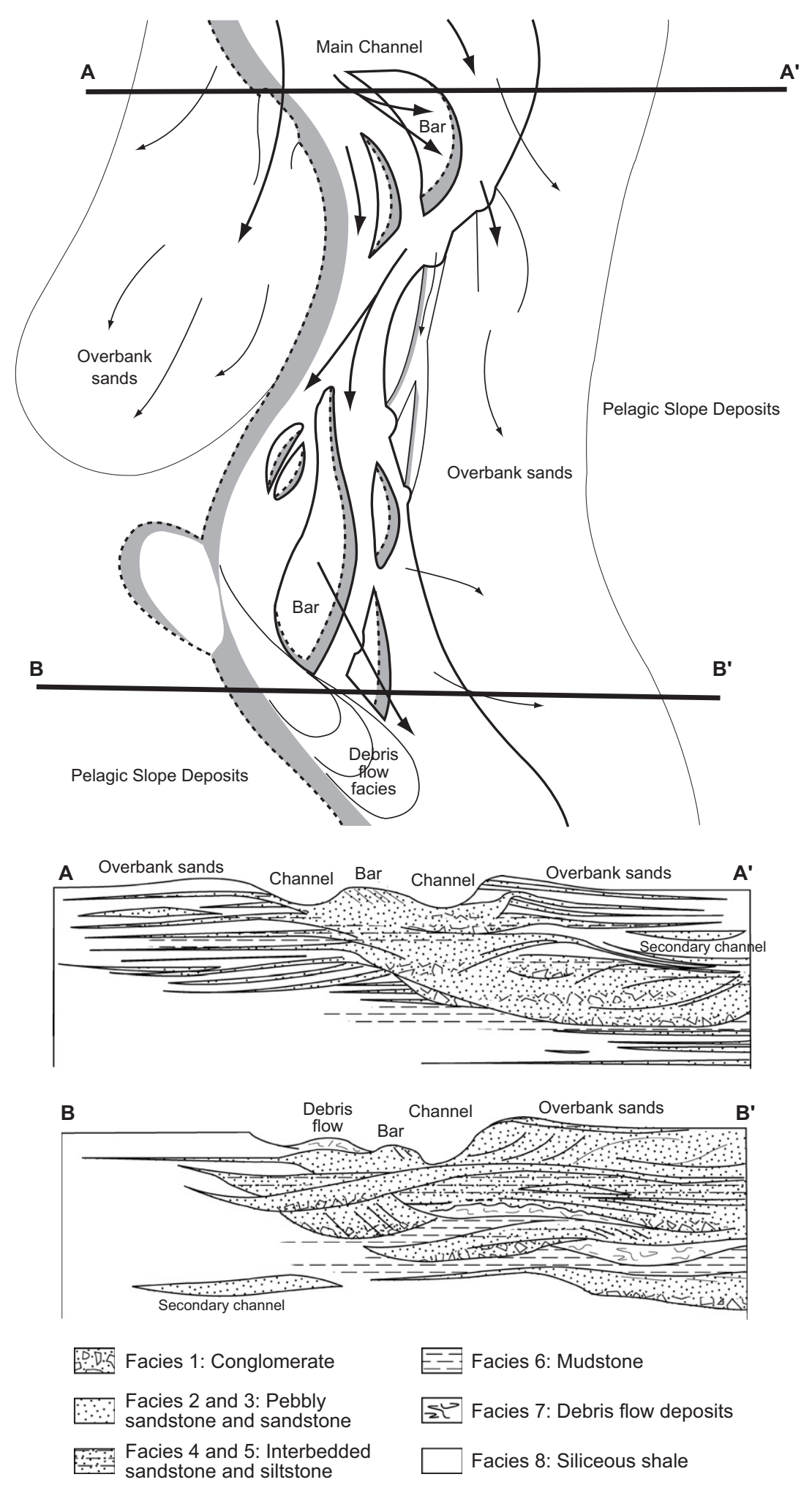

Fig. 12. Schematic plan view and cross-sections of the Gaviota slope gully deposits, illustrating the fairly straight, braided course of the channelized flows.

coarse-grained sediment suggests that sand and finer sediment bypassed the gully-fill region exposed at Gaviota.

The overall depositional setting for the facies observed at Gaviota likely consisted of crudely braided, low-sinuosity channels contained within the three isolated gullies (Fig. 12). Paleocurrent measurements do not deviate significantly throughout each of the nested channel sections or even between gully complexes (Fig. 5), which suggests prevalence of relatively straight channels consistent with slope gully formation. In addition, we have documented several medial channel bars typical of braided channels (Figs. 8 and 10), as well as contiguous channels at the same 
stratigraphic level (Fig. 8), perhaps reflecting bifurcation of a braided course. Overbank deposits are not widely distributed in the gully fill, and levee deposits are poorly developed if present at all. Finally, each of the gully systems shows overall westward migration (Figs. 2 and 13), but lack the point bar development that would be associated with meandering channels.

A schematic correlation section through Gully 1 illustrates the simplified overall geometry and facies architecture of the Gaviota submarine gully deposits (Fig. 13). Facies 1-3 are found exclusively within minor or major channel sequences. Facies 1 is generally restricted to the channel axis, whereas Facies 3 is usually found in channel margin regions. The pebbly sandstone of Facies 2 commonly forms the transition between Facies 1 and 3; the zone of Facies 2 lateral segregation is generally extremely narrow. Facies 2 pebbly sandstone beds may also form broad depositional sheets filling large channels or narrow lenticular beds infilling minor channel courses which lack Facies 1 conglomerate.

Within the gully complexes, thin-bedded sheet sandstone beds of Facies 4 are commonly interleaved with sandy siltstone of Facies 5 deposited between nested channel deposits. These inter-channel/intra-gully sands and silts may represent overbank sedimentation or simply interchannel lag deposits from a bypassing turbulent gravity flow. Out of the gully, sheets of Facies 4 interbedded with Facies 8 siliceous shale can be traced along strike directly into channel margin sandstones of Facies 3. This depositional association indicates that Facies 4 sandstone formed as out-of-gully overbank deposits.

The massive mudstone of Facies 6 represents background hemipelagic sedimentation between coarse-grained, channelized turbidite events and is typically intercalated with the channelized facies. Bioturbated beds of Facies 6 suggest that the gullies supported an infauna, in contrast to the poorly oxygenated ambient slope environment indicated by the unbioturbated, millimeter-scale laminated siliceous shale. Through a detailed analysis of trace fossils in the Monterey Formations, Ozalas et al. (1994) postulate that low oxygen levels were a primary control on infaunal colonization and concluded that biogenic reworking increased with increased oxygen levels during periods of relative sea level fall. Trace fossils present within the Gaviota deposits include diminutive Teichichnus, Planolites, Chondrites, Skolithos, and Thalassinoides. We interpret that oxygenated water was either funneled down the gullies, or burrowing organisms were transported into this suboxic environment and survived long enough to churn the sediment before perishing from suffocation (e.g., Follmi and Grimm, 1990).

Fig. 13 illustrates the westward shift in sedimentation characteristic of all three gullies. The first evidence of turbidity current sedimentation occurred with deposition of thin-bedded sandstone sheets of Facies 4 intercalated with Facies 8 siliceous shale of the Monterey Formation. Channel axis deposition represented by Facies 1-3 scoured the interbedded sandstone and siliceous shale on the eastern side of the gully, but no conglomerate exists at this stratigraphic level on the gully's western end. Instead, the western end was dominated by Facies 3 channel margin sands and Facies 4 and 5 overbank sand sheets, with two Facies 7 debris flow deposits likely associated with gully margin instability and slumping.

A debris flow deposit also occurred on the eastern end of the gully between the two main channel axis deposits, and deposition of coarse-grained material shifted west in the gully with deposition of a thick package of amalgamated Facies 1 conglomerate on top of the debris flow deposit. The conglomerate was covered by Facies 4 and 5 channel margin and overbank deposits associated with an adjacent channel. The westward shift in scour and fill of the gully continued with another series of channel axis deposits composed of Facies 1-3, with interbedded Facies 4 and 5 separating the main pulses of coarse-grained deposition. Facies 6 mudstone occurs in one tabular bed above the coarser-grained deposits, indicating a period of quiet hemipelagic sedimentation between the scouring and filling associated with turbidity currents. The entire scour and fill sequence is topped by several meters of interbedded Facies 4 and 5 which continues to the top of the outcrop.

\subsection{Implications for Quaternary gully systems}

Suggested causes for the origin of slope gullies include mass wasting/slumping, turbidity current scour, hyperpycnal flow down delta slopes, gas escape, and internal waves (Coleman et al., 1983; Field et al., 1999; Gardner, J.V., et al., 2003; Normark, personal communication, 2006). At Gaviota, thin turbibite beds intercalated with pelagic/ hemipelagic deposits that underlie the gully complexes may represent precursor events associated with incipient gully topography, but the sudden appearance of cobble to boulder-sized detritus filling scoured surfaces makes an erosional origin a near certainty. The presence of debrisflow deposits near the gully margins suggests that the Gaviota gullies probably initiated through local slope oversteepening from variable sediment accumulation, which then led to slope failure, slumping, and initiation of sediment flows (e.g., Pratson and Coakley, 1996; Spinelli and Field, 2001). Axial slopes in modern gullies off of San Clemente, California, are as steep as $31^{\circ}$ (Inderbitzen and Simpson, 1971); extremely coarse grain sizes and debrisflow deposits in the lower parts of the Gaviota gully fills are consistent with steep slopes. Once initiated, the gullies acted as sediment conduits from shelf and possibly onshore regions. Extrabasinal clasts of the Sespe Formation within the Gaviota conglomerate mean the gullies likely had an onshore source, although locally derived Monterey Formation clasts dominate. Headward slumping combined with continued turbidity current erosion would have lengthened the gullies, extending their reach further up the slope. This process is currently active on the modern 


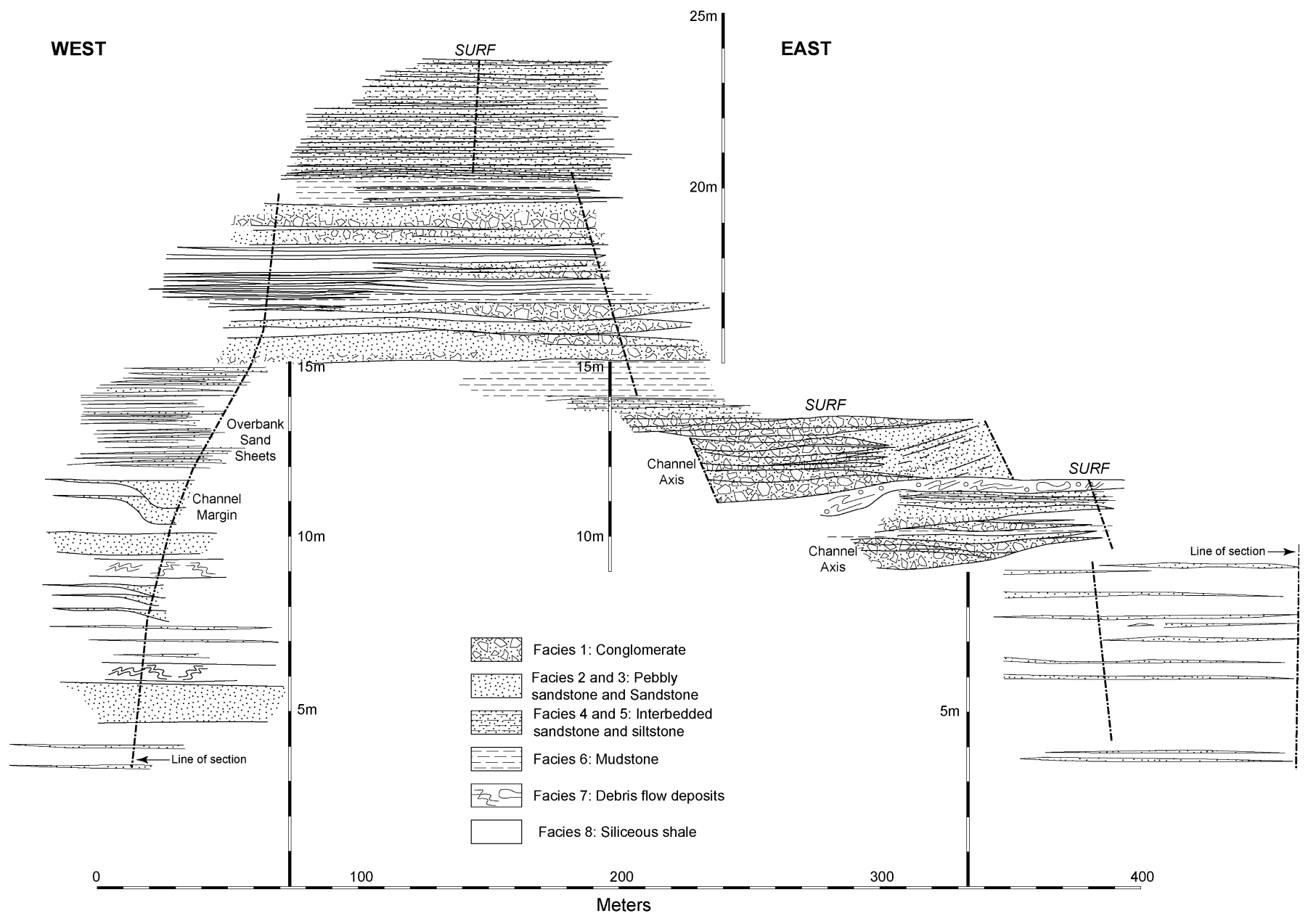

Fig. 13. Schematic correlation section through Gully 1 drawn between measured lines of section, which are indicated by dashed lines. 
slope just offshore of the Gaviota outcrop (Blum and Zumberge, 2006).

Multibeam surveys of slope gully systems off northern California and Italy suggest that following erosional initiation, slope gullies may accumulate combinations of acoustically layered and chaotic strata, inferred to represent turbidites and debris flows, respectively (Chiocci and Normark, 1992; Gardner, J.V. et al., 2003). The Gaviota gullies demonstrate the intercalation of positive relief sediment bodies of coarse-grained sediment (gravel bars and debris flow deposits), which would give rise to mounded, transparent to chaotic acoustic responses, as well as layered, sand-rich, intra-gully overbank deposits (Fig. 13). Surveys of Quaternary systems also reveal that gullies may remain spatially fixed for relatively long periods of time (e.g., $10^{3}-10^{5}$ years; Gardner, J.V. et al., 2003). Close examination of acoustic records suggests that gullies maintain position and relief through aggradation of draping hemipelagic deposits during periods when they are inactive as sediment transport conduits. The result is a propagation of gully complexes upward through the stratigraphic section (Fig. 1). The Gaviota gullies provide "ground-truth" support for these interpretations of acoustic imaging of Quaternary systems: lenticular coarsegrained units are restricted to the gully axis, and biosiliceous and fine-grained terrigenous stratal units blanket gully and inter-gully areas (Fig. 13), indicating that the gullies were episodically active as coarse sediment conduits. These relations also suggest that the instantaneous relief on the Gaviota gullies was likely less than $10 \mathrm{~m}$ (considering compaction), a number consistent with the modest relief of gullies on modern slopes (Table 1).

Gullies remain active as long as coarse detritus continues to reach gully heads, and many Quaternary gully systems show an overall tendency toward abandonment and hemipelagic draping during the Holocene sea level rise (e.g., Chiocci and Normark, 1992). In the cases of the Eel River basin slope of northern California and the Tiber delta slope of Italy, gully erosion events continued episodically, but hemipelagic draping, enhanced in accumulation rate by distal delta rain-out, results in eventual abandonment of the gullies (Chiocci and Normark, 1992). Gully relief may persist as relict gullies on the current sea floor or be damped out over time (Fig. 1). These acoustic records suggest that gully lithofacies should fine upward over the abandonment cycle. The Gaviota gully fills do indeed fine upward overall, and are capped by biosiliceous and hemipelagic stratal cover (Fig. 13). The Gaviota gullies evolved through time from erosionally initiated, active sediment conduits, characterized by alternating accumulation of lenticular coarse-grained deposits and tabular turbidite beds, to passive slope features draped by hemipelagic sediment. With time, periods of gully infilling and draping alternated, but overall aggradation eventually yielded complexes about $25 \mathrm{~m}$ thick (compacted thickness) before abandonment. The Gaviota complexes show minor westward migration of gully thalwegs throughout their depositional history, but no more lateral drift than is typical of stacked Quaternary examples (e.g., Gardner, J.V. et al., 2003).

\subsection{Implications for hydrocarbon reservoir systems}

Because the small scale of slope gullies is near the limits of resolution of conventional petroleum industry seismic surveys, developing diagnostic criteria for recognizing gully-fill deposits in boreholes is critical. These criteria include: (1) rapid textural and facies changes; (2) presence of coarse grain sizes; (3) prevalence of traction deposits and traction carpets; (4) very little fine-grained deposits or evidence of water escape indicative of collapsing sediment gravity flows; and (5) enclosing deposits have slope affinity.

The Gaviota gully fill is saturated with hydrocarbons but is exceptionally heterogeneous over short distances. The gully complexes clearly represent highly compartmentalized reservoir systems. Unsaturated lithologies include fine-grained draping facies and matrix-rich debris-flow deposits; oil-saturated lithologies vary sufficiently in grain size and sorting that they likely would produce oil differentially. The Gaviota outcrop demonstrates that prediction of reservoir compartment distribution is difficult, but extensive cut-and-fill in coarse facies may tend to enhance fluid communication and reduce compartmentalization.

Although hydrocarbon migration out of the top of the system is a risk inherent in exploring slope gully and canyon systems, several trapping mechanisms are possible. A rise in sea level likely will shut off coarse sediment supply to the gullies and cap the deposits with a flooding surface of impermeable mud. Likewise, a muddy slump deposit high in the system could potentially cap coarse-grained gully deposits and block further sedimentation in the gullies. Finally, gravitational slump faulting, perhaps associated with growth faults, could cut off the gullies from their sediment source and effectively stop further sedimentation. In this case, the faults themselves may facilitate escape of hydrocarbons along the fault surfaces.

The predictive value of recognizing ancient slope gullyfill deposits in the subsurface may prove as significant as their importance as hydrocarbon reservoirs. For instance, the dominance of medium to coarse sandstone and conglomerate facies throughout the gully-fill, combined with the abundant traction structures, suggests that a significant amount of sand and finer sediment bypassed the gully-fill region exposed at Gaviota. The bypassed sands may constitute a significant petroleum reservoir and should be found downslope from the gully deposits.

\section{Conclusions}

The small scale of the three-dimensional outcrop exposure of the Gaviota Beach gullies permits detailed study of the various slope gully sub-environments in one outcrop. Documenting and mapping channel axis, margin, 
and overbank sub-environments within the Gaviota gully fills enhances understanding of the sedimentologic processes that occur in the filling of slope gullies, common features on modern upper slopes and important conduits for transporting sediment to deeper water. Our results provide baseline data from which to develop diagnostic criteria for recognizing and characterizing similar smallscale slope features in the subsurface, and offer insight into the heterogeneity that may characterize slope gully petroleum reservoirs.

\section{Acknowledgments}

The authors wish to acknowledge the support of the corporate members of the Stanford Project on Deep Water Depositional Systems (SPODDS). These companies include Anadarko, BP, ChevronTexaco, Emerald Trail LLC, ENI-AGIP, ExxonMobil, Marathon, Occidental Petroleum, Perez Companc, Petrobas, Petrobas Energia (Pecom), Rohol-Aufsuchungs AG (RAG), Shell, and Unocal. We thank Ben Surpless, Amy Weislogel, and Steven Hubbard for assistance in the field as well as helpful comments, suggestions, and discussion. Andrea Fildani, and Bill Normark offered useful comments, and Michael Field kindly provided images used in Fig. 1. We thank Morgan Sullivan, D.M. Hodgson, Doug Masson, and Colin North for constructive reviews of an earlier version of the paper.

\section{References}

Atwater, T.M., 1970. Implications of plate tectonics for the Cenozoic tectonic evolution of North America. Geological Society of America Bulletin 81, 3513-3536.

Berggren, W.A., Kent, D.V., Swisher Jr., C.C., Aubry, M., 1995. A revised Cenozoic geochronology and chronostratigraphy. In: Berggren, W.A., Kent, D.V., Aubry, M., Hardenpol, J. (Eds.), Geochronology, Time scales and Global Stratigraphic Correlation, vol. 54. Society for Sedimentary Geology, Tulsa, OK, pp. 129-212 (special publication).

Blake Jr., M.C., Campbell, R.H., Dibblee Jr., T.W., Howell, D.G., Nilsen, T.H., Normark, W.R., Vedder, J.C., Silver, E.A., 1978. Neogene basin formation in relation to plate tectonic evolution of San Andreas fault system, California. AAPG Bulletin 62, 344-372.

Blum, J.A., Zumberge, M.A., 2006. Monitoring potential slope failure in the Santa Barbara basin using optical fibers. American Geophysical Meeting Fall Annual Meeting, poster OS43C-0675.

Buffington, E.C., Moore, D.G., 1963. Geophysical evidence on the origin of gullied submarine slopes, San Clemente, California. Journal of Geology 71, 356-370.

Chiocci, F.L., Normark, W.R., 1992. Effect of sea-level variation on upper-slope depositional processes offshore of Tiber Delta, Tyrrhenian Sea, Italy. Marine Geology 104, 109-122.

Cole, M.R., Armentrout, J.M., 1979. Neogene paleogeography of the western United States. In: Armentrout, J.M., Cole, M.R., TerBest Jr., H. (Eds.), Cenozoic Paleogeography of The Western United States. Pacific Section SEPM Pacific Coast Paleogeography Symposium 3, Los Angeles, California, pp. 297-323.

Coleman, J.M., Prior, D.B., Lindsay, J.F., 1983. Deltaic influences on shelfedge instability processes. In: Stanley, D.J., Moore, G.T. (Eds.), The Shelfbreak: Critical Interface on Continental Margins, vol. 33. Society of Economic Paleontologists and Mineralogists, pp. 121-137 (special publication).
Dibblee, T.W., Jr., 1950. Geology of southwestern Santa Barbara County, California. California Division of Mineralogy and Geology Bulletin, vol. $150,95 \mathrm{pp}$.

Dibblee, T.W., Jr., 1981. Geologic map of the Gaviota Quadrangle, California. US Geological Survey Open File Report 81-374.

Dott Jr., R.H., Bird, K.J., 1979. Sand transport through channels across an Eocene shelf and slope in southwestern Oregon, USA. In: Doyle, L.J., Pilkey, O.H. (Eds.), Geology of Continental Slopes, vol. 27. Society of Economic Paleontologists and Mineralogists, Tulsa, OK, pp. 327-342 (special publication).

Field, M.E., Clarke Jr., S.H., 1979. Small-scale slumps and slides and their significance for basin slope processes, southern California borderland. In: Doyle, L.J., Pilkey, O.H. (Eds.), Geology of Continental Slopes, vol. 27. Society of Economic Paleontologists and Mineralogists, Tulsa, OK, pp. 223-230 (special publication).

Field, M.E., Gardner, J.V., Prior, D.B., 1999. Geometry and significance of stacked gullies on the northern California slope. Marine Geology 154, 271-286.

Follmi, K.B., Grimm, K.A., 1990. Doomed pioneers: gravity-flow deposition and bioturbation in marine oxygen-deficient environments. Geology 18, 1069-1072.

Gardner, J.V., Dartnell, P., Mayer, L.A., Hughes-Clark, J.E., 2003. Geomorphology, acoustic backscatter, and processes in Santa Monica Bay from multibeam mapping. In: Lee, H.J., Weisberg, S. (Eds.), Integrated Assessment of An Urban Water Body, Santa Monica Bay, California. Marine Environmental Research, vol. 56, pp. 15-46.

Gardner, M.H., Borer, J.M., Melick, J.J., Mavilla, N., Dechesne, M., Wagerle, R.N., 2003. Stratigraphic process-response model for submarine channels and related features from studies of Permian Brushy Canyon outcrops, West Texas. In: Mutti, E., Steffens, G.S., Pirmez, C., Orlando, M., Roberts, D. (Eds.), Turbidites, Models and Problems. Marine and Petroleum Geology, vol. 20, pp. 757-787.

Govean, F.M., Garrison, R.E., 1981. Significance of laminated and massive diatomites in the upper part of the Monterey Formation, California. In: Garrison, R.E., Douglas, R.G. (Eds.), The Monterey Formation and Related Siliceous Rocks of California. Pacific Section SEPM Special Publication, Los Angeles, CA, pp. 181-198.

Hewlett, J.S., Jordan, D.W., 1993. Stratigraphic and combination traps within a seismic sequence framework, Miocene Stevens turbidites, Bakersfield Arch, California. In: Weimer, P., Posamentier, H. (Eds.), Siliciclastic Sequence Stratigraphy. AAPG Memoir 58. Tulsa, OK, pp. $135-162$.

Hornafius, J.S., Lagle, C.W., 1984. Magnetic stratigraphy and diatom biostratigraphy of the Monterey Formation at selected localities in the western Transverse Ranges, California. In: Garrison, R.E., Kastner, M., Zenger, D.H. (Eds.), Dolomites of The Monterey Formation and Other Organic-rich Units. Field Trip Guidebook-Pacific Section, vol. 41. Society of Economic Paleontologists and Mineralogists, Los Angeles, pp. 2-15.

Howell, D.G., Crouch, J.K., Greene, H.G., McCulloch, D.S., Vedder, J.G., 1980. Basin development along the late Mesozoic and Cainozoic California margin: a plate tectonic margin of subduction, oblique subduction, and transform tectonics. Special Publication of the International Association of Sedimentologists, vol. 4, pp. 43-62.

Hughes-Clarke, J.E., Mayer, L.A., 1996. Shallow-water imaging multibeam sonars: a new tool for investigating seafloor processes in the coastal zone and on the continental shelf. Marine Geophysical Researches 18, 607-629.

Inderbitzen, A.L., Simpson, F., 1971. Relationships between bottom topography and marine sediment properties in an area of submarine gullies. Journal of Sedimentary Petrology 41, 1126-1133.

Ingle Jr., J.C., 1973. Summary comments of Neogene biostratigraphy, physical stratigraphy, and paleoceanography in the marginal northeastern Pacific Ocean. In: Kulm, L.D., von Huene, R. (Eds.), Initial Reports of The Deep Sea Drilling Project, vol. 18. US Government Printing Office, Washington, pp. 949-959.

Ingle Jr., J.C., 1975. Summary of Paleogene-Neogene insular stratigraphy, paleobathymetry, and correlations, Philippine Sea and Sea of Japan 
region. In: Karig, D.E., Ingle, Jr., J.C. (Eds.), Initial Reports of The Deep Sea Drilling Project, vol. 31. US Government Printing Office, Washington, pp. 837-855.

Ingle Jr., J.C., 1980. Cenozoic paleobathymetry and depositional history of selected sequences within the southern California continental borderland. Cushman Foundation Special Publication 19 , $163-195$.

Isaacs, C.M., 1980. Diagenesis in the Monterey Formation examined laterally along the coast near Santa Barbara. Ph.D. Thesis, Stanford University, Stanford, California, 329pp.

Isaacs, C.M., 2001. Depositional framework of the Monterey Formation. In: Isaacs, C.M., Rullkoetter, J. (Eds.), The Monterey Formation: From Rocks to Molecules. Columbia University Press, New York, pp. $1-30$.

Kennett, J.P., 1977. Cenozoic evolution of Antarctic glaciation in the circum-Antarctic Ocean, and their impact on global paleoceanography. Journal of Geophysical Research 82, 3843-3860.

Lowe, D.R., 1982. Sediment gravity flows: II. Depositional models with special reference to the deposits of high-density turbidity currents. Journal of Sedimentary Petrology 52, 279-297.

Ozalas, K., Savrda, C.E., Fullerton Jr., R.R., 1994. Bioturbated oxygenation-event beds in siliceous facies: Monterey Formation (Miocene), California. Palaeogeography, Palaeoclimatology, Palaeoecology $112,63-83$.

Pickering, K.T., Hiscott, R.N., Hein, F.J., 1989. Submarine canyons, gullies, and other sea valleys. In: Deep Marine Environments: Clastic Sedimentation and Tectonics. Unwyn Hyman, London, UK, pp. 133-159.

Pisciotto, K.A., Garrison, R.E., 1981. Lithofacies and depositional environments of the Monterey Formation, California. In: Garrison, R.E., Douglas, R.G. (Eds.), The Monterey Formation and Related
Siliceous Rocks of California. Pacific Section, SEPM Special Publication, Los Angeles, pp. 97-122.

Posamentier, H.W., Basden, W.A., 2000. Depositional systems at the continental margin: 3D seismic case study from offshore Northeast Java. AAPG Bulletin 84, 1477.

Pratson, L.F., Coakley, B.J., 1996. A model for the headward erosion of submarine canyons induced by downslope-eroding sediment flow. Geological Society of America Bulletin 108, 225-234.

Ricketts, B.D., Evenchick, C.A., 1999. Shelfbreak gullies, products of sealevel lowstand and sediment failure: examples from Bowser Basin, northern British Columbia. Journal of Sedimentary Research 69, $1232-1240$.

Shepard, F.P., 1965. Types of submarine valleys. Bulletin of the American Association of Petroleum Geologists 49, 304-310.

Spinelli, G.A., Field, M.E., 2001. Evolution of continental slope gullies on the northern California margin. Journal of Sedimentary Research 71, 237-245.

Surlyk, F., 1987. Slope and deep shelf gully sandstones, Upper Jurassic, East Greenland. AAPG Bulletin 71, 464-475.

Ward, R.B., 1984. Sedimentology, diagenesis, and provenance of the slope channel deposits exposed within the upper siliceous member of the Monterey Formation exposed west of Gaviota Beach, California. M.A. Thesis, Stanford University, Stanford, CA, 101pp.

Woodruff, F., Savin, S.M., 1985. $\partial^{13}$ C values of Miocene Pacific benthic foraminifera: correlations with sea level and biological productivity. Geology 13, 119-122.

Yeats, R.S., 1979. Stratigraphy and paleogeography of the Santa Susana fault zone, Transverse Ranges, California. In: Armentrout, J.M., Cole, M.R., TerBest Jr., H. (Eds.), Cenozoic Paleogeography of The Western United States. Pacific Section, SEPM Pacific Coast Paleogeography Symposium 3, Los Angeles, California, pp. 191-204. 